\title{
Environmental risks of car tire microplastic particles and other road runoff pollutants
}

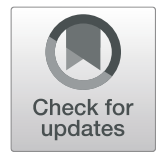

Jacqueline E. Tamis ${ }^{*}$ (D), Albert A. Koelmans ${ }^{2}$, Rianne Dröge ${ }^{3}$, Nicolaas H. B. M. Kaag ${ }^{1}$, Marinus C. Keur ${ }^{1}$, Peter C. Tromp ${ }^{3}$ and Ruud H. Jongbloed ${ }^{1}$

\begin{abstract}
Tire wear represents a large source of microplastic entering the aquatic environment, however little is known about its environmental risks. Here, we provide the first assessment of the environmental risks of pollution with tire wear microplastic particles (TWP) and associated organic micropollutants present in road runoff in Europe, in one go. Besides microplastic TWP, the assessment focused on priority substances as defined by the Water Framework Directive (WFD). In addition, several other pollutants (mercaptobenzothiazole, tolyltriazole, diisodecyl phthalate and hexa (methoxymethyl)melamine) were included. The risk assessment comprised a hazard identification (selection of traffic related substances), an assessment of exposure (Predicted Environmental Concentrations, PECs), based on estimated and measured values, effect assessment (selection of Predicted No Effect Concentrations, PNECs, and effect values) and a risk characterization (PEC/PNEC and Species Sensitivity Distributions (SSDs)). Whole Effluent Toxicity (WET)-tests on samples taken from road runoff, surface water and sediment were conducted as a retrospective approach to support the risk assessment. We demonstrate that risks exist for TWP and for several TWP-associated chemical substances in surface water and sediment. In addition, WET-tests of the runoff samples showed significant dose-related effects for algae. However, WET-tests of surface water showed no significant toxic effects. The present study provides opportunities to protect the quality of European waters from complex road runoff pollution, focusing on TWP microplastic, their associated WFD priority substances and other hazardous substances.
\end{abstract}

Keywords: Tire wear particles, Road runoff, Microplastic, Organic micropollution, Environmental risk assessment, Whole effluent toxicity test

\section{Introduction}

Microplastics are of increasing concern in the environment $[1,2]$. Tire wear is estimated to be one of the largest sources of microplastics entering the aquatic environment [3-7]. The mechanical abrasion of car tires by the road surface forms tire wear particles (TWP) [8] and/or tire and road wear particles (TRWP), consisting of a complex mixture of rubber, with both embedded asphalt and minerals from the pavement [9]. In our study we focus on tire wear particles as a component of

\footnotetext{
* Correspondence: jacqueline.tamis@wur.nl

${ }^{1}$ Wageningen Marine Research, Ankerpark 27, Den Helder 1781 AG, the Netherlands

Full list of author information is available at the end of the article
}

microplastics in the aquatic environment. Therefore the abbreviation TWP is used to indicate particles originating from road-generated tire abrasion. Small TWP are typically emitted into the air and prone to air dispersal, whereas large TWP will get deposited on the road surface where some parts will get trapped and other parts will be transported by rainwater runoff into soils, sewers and/or surface waters [4]. TWP are present in all environmental compartments, including air, water, soils/sediments, and biota [10]. Pure TWP are rarely found in the environment as it is mostly of mixed composition, i.e. consisting of tire and other road related wear particles [11]. Hence, the term TRWP may be more appropriate when referring to tire wear particles in the environment 
[12]. Recently, a nomenclature on anthropogenic polymer particulates has been proposed, introducing microrubber (MR) as an umbrella term covering all micronized rubber particles such as T(R) WP [13]. TWP contain rubber polymers (about 50\%) and other components such as fillers and softeners $[7,11,12]$. Road runoff including TWP has been studied extensively over the past decades, addressing characteristics, environmental concentrations and effects of TWP [9, 10, 14-17], with an additional focus on (effects of) leaching of heavy metals and other trace elements [18-34]. Leachability of toxic compounds differs greatly among different tires (i.e. rubber formulas) [26] and different tires were found to vary in toxicity by 2 orders of magnitude [23]. Tire components may also form toxic transformation products. Recently, a previously unknown transformation product of a globally ubiquitous tire rubber antioxidant was identified as the primary causal toxicant for decades of stormwater-linked salmon acute mortality observations in the U.S. [35]. Furthermore, toxicity of TWP leachates is also related to the leaching methods used to prepare and extract the tire particles [15]. Harmful effects from TWP leachates were observed on aquatic organisms including algae, crustacean and fish, although significant effects were not always determined $[9,15,17$, $21,26]$. The acute effect concentrations of TWP leachates (TWP removed) in aquatic media, including marine environments, were found to cover a range of 25 to 100 , $000 \mathrm{mg}$ TWP/L $[8,36]$, while chronic effect concentrations vary from 10 to $3600 \mathrm{mg}$ TWP/L [8]. A Predicted No-Effect Concentration for water (PNEC water) of 3.9 mg TWP/L was derived based on TWP leachate [10]. Although expressed in TWP mass, these effect values are all based on the chemicals leaching from TWP and not on the particles themselves. Components of leachates found to be largely responsible for the toxicity were zinc and organic compounds $[17,26]$.

The briefly described literature above indicates an extensive knowledge base is available for TWP leachates. For TWP as a component of microplastics, knowledge on the concentrations, degradation, retention and toxicity of in the aquatic environment is however limited $[12,37,38]$. Due to interactions with other particulate matter, TWP are subjected to changes in morphology and composition, which makes it difficult to track and quantify them in the environment [8]. Environmental concentrations of TWP have been measured using markers $[16,39]$, i.e. tire constituents which occur in specific concentrations in tire material [8]. This approach is limited due to multiple sources of most available marker substances and variations of the marker content in the tires [8]. The presence of actual TWP was first detected as airborne particles, e.g. [11], indicating tire wear as a significant contribution to the flux of microplastics into the environment. Recently, TWP have been measured in stormwater [40], sediment and surface water [41], confirming that road runoff likely is an important pathway of microplastic pollution. Therefore, there is a need to evaluate the effect of TWP on biota and to assess potential ecological risks posed by TWP.

Effects in the aquatic environment may stem from TWP itself or from compounds released from TWP [8, 42-44]. Furthermore, other traffic related sources (brakes, lubricants, coolants, asphalt, road marking and vehicle parts) may also release microplastics and other pollutants $[4,29,45-59]$. A wide range of species are capable of ingesting microplastics and 'food dilution' has been found to be the effect mechanism with the highest weight of evidence $[60,61]$. Considering TWP, ingestion by aquatic species has recently been confirmed and a dissimilar mechanism of toxicity of TWP and leachate was suggested [44]. Therefore, when addressing risks of microplastics from road runoff, one needs to consider the toxicity of the microplastic particles themselves, the toxicity of tire compounds which may or may not leach out of the particles, as well as the toxicity of other pollutants in road runoff. With a few exceptions [42-44], available research on TWP has been limited to forced TWP leachates, thus disregarding the actual particles [8]. To date, we are not aware of studies that assess the risks of TWP including both the chemical as well as the particle effect modes of action in one go.

This study aims to provide insight in risks of pollution in road runoff for European waters by conducting a risk assessment for the components in road runoff that can be considered hazardous. Following Diamond et al. [62] the assessment comprised of a generic prospective assessment using conservative assumptions to identify potential ecological risks (Predicted environmental concentration (PEC) / Predicted no-effect concentration (PNEC) ratio), followed by a higher resolution prospective assessment (Species Sensitivity Distributions (SSDs) used to estimate the Potentially Affected Fraction (PAF) of species) and then by a retrospective assessment (Whole Effluent Toxicity (WET)-tests). In relevance to European water quality, the prospective risk assessment was focused on WFD priority substances (Directive 2013/39/EU), supplemented with other hazardous substances found in road runoff. As the number of different compounds potentially present in road runoff is high (306 compounds [29]), a selection was made of 10 substances and TWP itself to be included in the risk assessment. Estimated and measured exposure concentrations (PECs) of these pollutants reported in literature were compared to the sensitivity of the environment as represented by 1) PNECs and 2) SSDs [63]. Due to lack of effect data for TWP as a specific subcategory of microplastic, we used generic microplastics data as a 
proxy to estimate their particle related effects and hence

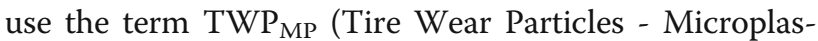
tic). Whole Effluent Toxicity (WET)-tests using bacteria, algae and crustacea were conducted to support the risk assessment in retrospect [62]. With this retrospective assessment realistic field samples are tested and combination toxicology as well as yet unidentified substances are covered.

\section{Methods}

To provide insight in risks of pollution in road runoff for European waters, a risk assessment of individual substances in road runoff was conducted. This risk assessment comprised hazard identification (selection of substances), exposure assessment, effect assessment and risk characterization [64]. Following Diamond et al. [62], this prospective risk assessment was combined with a retrospective assessment in the form of Whole Effluent Toxicity (WET)-tests on representative environmental samples. The prospective risk assessment is used to identify potential ecological risks whereas the retrospective assessment provides additional information that integrates the complexity of real mixtures.

\section{Selection of substances}

The group of microplastics, or more specific $\mathrm{TWP}_{\mathrm{MP}}$, was selected as primary focus of this study. We use the term microplastics to refer to the group of microplastic particles in general, with particle sizes ranging from 1 to $5000 \mu \mathrm{m}[61,65,66]$, whereas TWP refers to the particles from tires with sizes within the range of microplastics [14]. Besides microplastic particles, tire compounds and other pollutants in road runoff needed to be identified for inclusion in the risk assessment. To select a most relevant and also manageable number of TWPassociated compounds for the risk assessment, $10 \mathrm{com}$ pounds were selected from a list of organic micropollutants that are reported to be released from traffic and roads (Supporting information: Table S1 to S3, page 412). Selection criteria were as follows. First, compounds listed as priority substance under the Water Framework Directive (WFD 2000/60/EC) were selected: Benzo(a) pyrene (BaP); Fluoranthene; Nonylphenol (NP); 4-tertoctylphenol (OP); Di (2-ethylhexyl) phthalate (DEHP). One substance, Bisphenol A (BPA), is considered to be a potential candidate for eventual priority substance status under article 16 of the WFD and was also selected. Four other substances were selected based on the following criteria (1) concentrations in runoff are reported in literature, (2) the pollutants originate from a variety of sources and (3) the pollutants are expected to dominate risk, based on the assessment by Baun et al. [67] and Markiewicz et al. [29]. The latter assessment prioritizes pollutants with properties such as: low volatility; persistent; risk for bioaccumulation; risk for toxicity; and long-term adverse effects. These four substances are Mercaptobenzothiazole (MBT); Tolyltriazole (TT); Diisodecyl phthalate (DIDP); and Hexa (methoxymethyl) melamine (HMMM).

\section{Exposure assessment}

Measured values reported in literature in runoff or storm water were taken as the Predicted Environmental Concentration (PEC) in runoff (all values found in literature are provided as Supporting information, Table S4 on page 13-15).

For the PEC in surface water, both estimated (extrapolated from runoff concentrations) and measured values (reported in literature) were used. For the estimated values it was assumed that the concentration in a water body equals the runoff concentration divided by 100 . When more than one PEC in runoff was available, the maximum (worst case) value was taken for the derivation of the PEC in surface water. The dilution factor of 100 is derived for a typical small surface water body ( 2 $\mathrm{m}$ wide and $1 \mathrm{~m}$ depth) with a flow of $1 \mathrm{~m}^{3} / \mathrm{sec}$, combined with a typical discharge from a rain event of 30 $\mathrm{mm}$ in $1 \mathrm{~h}$ on a road of $100 \mathrm{~m}$ long and $12 \mathrm{~m}$ wide (resulting in a discharge of $0.01 \mathrm{~m}^{3} / \mathrm{sec}$ ). For relatively small and/or stagnant surface water bodies that are mainly loaded with road runoff water, the dilution factor of 100 may be too high. For those water bodies, the risk assessment based on runoff concentrations is more relevant. The estimation was only applied for the 10 substances, as the dilution assumption does not apply for particles (TWP). The estimated TWP concentration is based on a conceptual model of TRWP fate [37].

For the PEC of sediment, the same approach was used as for surface water. The estimated value for each of the 10 substances was extrapolated from measured values in the solid fraction of runoff by using a dilution factor of 100. In case no concentration in runoff sediment was available, a fixed ratio of 10 between the PEC surface water and PEC sediment was assumed, based on the ratio between surface water concentrations and sediment concentrations of phenols and phthalates in Björklund et al. [68]. A list of estimated and measured values in surface water and sediment is provided as Supporting information (Tables S4 and S5 on page 13-16).

\section{Effect assessment PNEC selection or derivation}

The PNEC is defined as the concentration of the substance below which adverse effects in the environmental sphere of concern are not expected to occur (Regulation (EC) No. 1907/2006). For each substance, a PNEC water and PNEC sediment was selected from (in order of priority): 
- Existing EU standards, i.e. Environmental Quality Standards (EQS). EQS are available for priority substances (Directive 2008/105/EC and related documents);

- PNEC values reported in EU Risk Assessment Reports;

- PNEC values reported on the ECHA website (https://echa.europa.eu/substance-information/);

- PNEC values reported in literature.

In case there was no PNEC value available from the above sources, a PNEC was derived using available toxicity information in combination with an appropriate safety factor as indicated by the EU Technical Guidance Document [64]. Therefore a search was conducted in the US-EPA ECOTOX database (https:// cfpub.epa.gov/ecotox/), which is a comprehensive, publicly available knowledgebase providing single chemical environmental toxicity data. If toxicity data was still limited, a search was performed in peerreviewed literature using the search engine SCOPUS (www.scopus.com) and, if necessary, in grey literature (e.g. using google-scholar). In case a PNEC sediment was not available in literature and toxicity data for benthic species was lacking, the PNEC sediment was estimated based on equilibrium partitioning [64] of the organic compounds. All PNECs and their literature sources or derivation (including chemical equilibrium equations) are provided and explained in detail as Supporting information (page 17-22).

\section{Effect data search}

A search for No Observed Effect Concentration (NOEC) values was conducted to provide input for the SSD approach (see Risk characterization below). To enlarge the availability of ecotoxicological data we also searched for effect concentrations up to $10 \%\left(\mathrm{EC}_{0}\right.$ to $\mathrm{EC}_{10}$, with $\mathrm{EC}_{\mathrm{x}}$ as the effect concentration at which $\mathrm{x} \%$ effect (mortality, inhibition of growth, reproduction, etc.) is observed compared to the control group) to represent NOEC values, and for acute $\mathrm{EC}_{50}$ and $\mathrm{LC}_{50}$ (Lethal Concentration $50 \%$ ) values. For the latter values, a pragmatic acute to chronic ratio of 10 was used [69] to represent the NOEC. As toxicity values for sediment are scarce, we limited our search to the water phase.

The US-EPA ECOTOX database (https://cfpub.epa. gov/ecotox/) was searched using the CAS numbers of the 10 selected substances. The search results (Table S15) were checked for relevance according to the following criteria:

- Only relevant endpoints (NOEC; $\mathrm{EC}^{\mathrm{L}} \mathrm{LC}_{0}$ to $10 ; \mathrm{EC}_{50}$, $\mathrm{LC}_{50}$ );
- Concentration must be expressed as environmental concentration (i.e. exposure: $\mathrm{mg} / \mathrm{l}, \mu \mathrm{g} / \mathrm{l}$ ) and not in food or organism (i.e. dosage: $\mathrm{mg} / \mathrm{kg}$ bw etc.);

- Only exact numerical values were selected, in other words, effect concentrations reported as: 'NR'; greater than ('>'); smaller than ('<'), or approximate $(\stackrel{\sim}{\prime})$ were not included.

\section{Risk characterization}

The risk assessment followed two approaches: 1) calculation of the PEC/PNEC ratio, indicating whether unacceptable effects on organisms are likely to occur and; 2) comparing the PEC with an SSD, to indicate the probability that a specific fraction of species is exposed above their no effect value; the Potentially Affected Fraction of species (PAF) [70]. The SSD approach uses the lowest available NOEC per species [71-74]. When more than one value was found for the same species under similar conditions, i.e. same end-point and an analysis of the test conditions used cannot explain the difference in observed response, the geometric mean of these values was used. The minimum number of species required when using the SSD method is 10 (preferably more than 15) covering at least 8 taxonomic groups [64]. Because of these requirements and acknowledging the scarcity of sediment toxicity values, the probabilistic risk assessment was focused on the water phase only.

When sufficient NOECs were available for a substance, an SSD was constructed, by using the software ETX 2.1 [75] which is freely available at https://rvs.rivm.nl/ risicobeoordeling/modellen-voor-risicobeoordeling/ETX. ETX 2.1 applies a cumulative log-normal distribution, where sensitivity values for species are fitted to a logarithmic scale. The SSD was used to estimate the PAF, see e.g. European Commission [64] and Aldenberg \& Slob [76]. Using the SSDs, the PAF at the exposure concentration (PEC) is estimated as a median estimate $(50 \%$ confidence), plus lower estimate (5\% confidence) and upper estimate ( $95 \%$ confidence) of the fraction affected.

\section{Whole effluent toxicity (WET)-tests}

Additional to the risk assessment, WET-tests were executed to assess the toxicity of runoff and of surface water next to a highway. In contrast to our prospective risk assessment, the WET-tests constitute a retrospective, empirical approach [62].

Road runoff samples were taken in Germany and Sweden. In Germany, on 18 March 2019 runoff samples have been gathered from the highway A61 between Kreuz Meckenheim and Dreieck Bad NeuenahrAhrweiler (at the parking place 'Goldene Meile', Coordinates: $50.58 \mathrm{~N}, 7.06 \mathrm{E}$ ). On the sampling day, it was partly cloudy and there was some precipitation $(0.4 \mathrm{~mm}$ in Köln-Bonn Flughafen) with a maximum temperature 
of 10 degrees Celsius. There was more precipitation registered in Köln-Bonn Flughafen on the days before the sampling day (2.3-18.2 $\mathrm{mm}$ per day in the 5 days before the samples were gathered). Highway A61 is a busy highway with 5 lanes in total and an emergency lane with an average traffic intensity of 73,310 vehicles per day. The asphalt consists of normal asphalt. In Sweden, on 14 June 2019 samples have been gathered from the Swedish National Road and Transport Research Institute (VTI) test site located at the highway E18 (Coordinates: $59.63 \mathrm{~N}, 16.86 \mathrm{E}$ ). Water samples were collected from a concrete storm water well containing road runoff water. On the sampling day, it was cloudy at first (no rain), and later sunny, with a temperature of 18-21 degrees Celsius. In the days before the sampling, there was some rain measured at weather station Enköping Mo (0-13 $\mathrm{mm}$ per day in the 5 days before the sampling). Highway E18 is a highway with 2 lanes in each direction (4 lanes in total) and no emergency lane, with an average traffic intensity of 21,300 vehicles per day and the asphalt consists of stone mastic asphalt. Surface water samples have been taken in the Netherlands, in a surface water body next to the A2 highway (Coordinates: $52.24 \mathrm{~N}, 4.98 \mathrm{E}$ ), on 17 April 2019. Samples were collected from the center of the water body; 101 surface water just under the surface at approx. $30 \mathrm{~cm}$ depth. On the sampling day, the weather was partly cloudy (no rain) with a maximum temperature of 16 degrees Celsius. The last rain event occurred 2 weeks before the sampling. It should be realized that the surface water samples reflect time integrated concentrations from emission pulse loadings (runoff events) already diluted and transported in the receiving environment. This renders a longer term interpretation and does not include such short term weather dynamics. Highway A2 is a busy highway with 5 lanes in each direction (10 lanes in total) and an emergency lane with an average traffic intensity of 190,000 vehicles per day. The asphalt consists of porous asphalt, which reduces the amount of pollutants that could reach the surface water body. To maintain the in situ state of the compounds, samples were preserved as follows. All samples were stored in green/brown colored glass bottles or jars in the dark at $4 \pm 3$ degrees Celsius. This implies that degradation by UV and changes in toxicity profiles were prevented. Sample preservation by use of biocides was avoided because that would change the toxicity of the samples. During transport the samples were cooled with cooling elements. The samples arrived at the laboratory and were tested in August 2019. At arrival the samples were stored at $7{ }^{\circ} \mathrm{C}$. Before being used in the WET-test, the temperature was gradually brought back to room temperature.

WET-tests enable the evaluation of combination toxicity and yet unidentified toxicants in a natural matrix.
Fresh water WET-tests were performed for species from multiple tropic levels, namely bacteria (Vibrio fischeri), algae (Raphidocelis subcapitata) and crustacea (Daphnia magna). The samples contained some solids, which easily settled out. To avoid interference with the measurements, the overlying water was used (elutriate) after settling out for $24 \mathrm{~h}$. The tests were done on dilution series of these overlying water samples. In the algal growth inhibition test (ISO guideline 8692 (2012)), adapted for micro volumes [77] and the Daphnia immobilization test (ISO guideline 6341 (2012)), the concentration series used (expressed as \% of the chemical concentration in the original sample) was $0 \%$ (blank), 31.6\%, 42.2\%, 56.2\%, 75\% and 100\%, assuming toxicity will be moderate to low. For the Microtox test with Vibrio fischeri, the range was adapted to meet the requirements of the Microtox test, with a maximum of $45 \%$ sample due to dilution of the sample with the bacterial suspension (ISO guideline 11,348-3 (2007)). Experimental details of the WET-tests are provided as Supporting information (page 2 and 3).

The NOEC is derived from the data noting that the effect at the NOEC should not exceed $10 \%$ of the tested population [64]. The $\mathrm{EC}_{50}$ was calculated using a 'sigmoidal dose-response curve' with variable slope and is based on the effect in the test concentrations relative to the blank condition.

\section{Results \\ Exposure assessment}

The average, minimum and maximum values of the reported concentrations in runoff found in literature were used as PECs runoff (Table 1). For the PEC in surface water and sediment, both estimated (extrapolated from runoff concentrations) and measured values (reported in literature) were used (Table 2).

\section{Effect assessment \\ PNEC selection or derivation}

For all organic substances, $\mathrm{PNEC}_{\text {water }}$ and $\mathrm{PNEC}_{\text {sediment }}$ values were taken from literature or were derived (Table 3). For five substances (BaP, Fluoranthene, NP, OP, DEHP), EQS were available, which apply under the WFD for surface waters in Europe [96]. For most other organic substances PNEC values were available in the literature. Exceptions are the $\mathrm{PNEC}_{\text {water }}$ and $\mathrm{PNEC}_{\text {sediment }}$ of DIDP and the PNEC $_{\text {sediment }}$ of HMMM, which were derived by using ecotoxicity values from literature combined with an assessment factor and/or the equilibrium method as described in the Supporting Information (page 18-20). For TWP, PNEC values including the particle effect modes of action were not available. Therefore PNEC values for microplastics (MP) available in the 
Table 1 Predicted environmental concentrations (PECs) in runoff (water phase and solids) based on measured values (average, minimum and maximum) reported in literature (see Supporting information, Table S4)

\begin{tabular}{llll}
\hline Pollutant $^{\mathbf{b}}$ & Runoff water $(\boldsymbol{\mu g} / \mathbf{l})$ & Runoff solids $\left(\boldsymbol{\mu g} / \mathbf{g}_{\mathbf{d w}}\right)$ & Reference \\
\hline TWP & $29,737(975-58,500)$ & $148,040\left(520^{\mathrm{a}}-390000^{\mathrm{a}}\right)$ & {$[78-80]$} \\
BaP & $0.28(0.0008-0.83)$ & $0.58(0.21-0.94)$ & {$[78,81]$} \\
BPA & $0.23(0.03-0.55)$ & $0.15(0.06-0.24)$ & {$[78,82]$} \\
DEHP & $1.22(0.66-2.27)$ & $55.30(2.44-98.00)$ & {$[78,83]$} \\
DIDP & $3.93(0.60-8.60)$ & $72.10(4.61-139.59)$ & {$[78,83]$} \\
FI. & $1.22(0.003-3.65)$ & $1.36(0.30-2.41)$ & {$[78,81]$} \\
HMMM & $2.32(0.88-3.89)$ & $0.017(0.002-0.032)$ & {$[78,84]$} \\
MBT & $0.043(0.010-0.110)$ & $0.60(0.19-1.01)$ & {$[78,85]$} \\
NP & $0.13(0.01-0.36)$ & $1.03(0.001-3.1)$ & {$[78,82]$} \\
OP & $0.091(0.016-0.197)$ & $0.99(0.53-1.45)$ & {$[78,82]$} \\
TT & $0.90(0.010-2.30)$ & $0.57(0.039-1.10)$ & {$[78,85]$} \\
\hline
\end{tabular}

${ }^{a}$ Concentration in solids reported in literature in ww and here converted to $\mathrm{dw}$ using a factor of 2.6

bollutants: BaP Benzo(a) pyrene, BPA Bisphenol A, DEHP Di (2-ethylhexyl) phthalate, DIDP Diisodecyl phthalate, FI. Fluoranthene, HMMM Hexa (methoxymethyl) melamine, MBT Mercaptobenzothiazole, MP Microplastics, NP Nonylphenol, OP 4-tert-octylphenol, TWP Tire Wear Particles, $T$ Tolyltriazole

literature were used to represent the PNEC for TWP, i.e. TWP $_{\text {MP. }}$

\section{Effect data search}

A total of 63 effect values were gathered for microplastic (Supporting information, Table S15) which were used to derive the SSD for $\mathrm{TWP}_{\mathrm{MP}}$ (Supporting information, Figure S1). For the organic micropollutants a total of 1823 effect values were gathered (Supporting information, Table S16) which were used to derive the SSDs for
BaP, BPA, DEHP, Fluoranthene, NP, and OP (Supporting information, Figures S2-S7). Only a few values were found for DIDP and TT and for HMMM there were no values available. No SSDs could be derived for these substances.

\section{Risk characterization}

The PNEC values have been compared with concentrations, in runoff (Fig. 1) and in surface water and sediment (Fig. 2) in order to derive an indication of risk (PEC/PNEC ratio). A PEC/PNEC ratio higher than 1 indicates that unacceptable effects on organisms are likely to occur; the higher the ratio, the more likely that unacceptable effects may occur [64]. For road runoff water, the maximum PEC/PNEC is higher than 1 for $\mathrm{TWP}_{\mathrm{MP}}$, $\mathrm{BaP}, \mathrm{DEHP}, \mathrm{DIDP}$, fluoranthene, NP and OP (Fig. 1). For solids in runoff, the $\mathrm{PEC} / \mathrm{PNEC}$ ratios are higher than 1 for $\mathrm{TWP}_{\mathrm{MP}}$, BPA, DIDP, fluoranthene, MBT, OP and TT. For surface water, ratios exceeds 1 for $\mathrm{TWP}_{\mathrm{MP}}$, $\mathrm{BaP}$ and fluoranthene in water. For sediment, ratios exceeds 1 for $\mathrm{TWP}_{\mathrm{MP}}$, OP and TT.

For the probabilistic risk assessment, sufficient data for deriving an SSD was gathered for $\mathrm{TWP}_{\mathrm{MP}}$, BaP, fluoranthene, NP, OP, DEHP and BPA (SSDs provided as Supporting information (page 23-30). For MBT, TT, DIDP and HMMM the data availability did not meet the requirements for SSD derivation [64] and therefore the PAF could not be estimated for these substances. Using the SSDs, the PAF at the exposure concentrations (PECs) is estimated as a median estimate (50\% confidence), plus lower estimate (5\% confidence) and upper estimate (95\% confidence) of the fraction affected [75]. All PAF estimates are provided as Supporting

Table 2 Predicted environmental concentrations (PECS) in surface water and sediment based on measured values (reported in literature) and estimated values (extrapolated from maximum runoff concentrations (Table 1)), see Supporting information, Table S5

\begin{tabular}{llll}
\hline Pollutant $^{\mathbf{c}}$ & Surface water $(\boldsymbol{\mu g} / \mathbf{l})$ measured / estimated & Sediment $\left(\boldsymbol{\mu g} / \mathbf{g}_{\mathbf{d w}}\right)$ measured / estimated & Reference $(\mathbf{m e a s u r e d}$ value $)$ \\
\hline TWP & $8.00(6.00-10) / 120$ & $552\left(5.98^{\mathrm{a}}-1900^{\mathrm{a}}\right) / 1200^{\mathrm{b}}$ & {$[41,78,79]$} \\
BaP & $0.0001 / 0.0083$ & $0.073 / 0.0094$ & {$[78]$} \\
BPA & $0.01 / 0.0055$ & $0.001 / 0.0024$ & {$[78]$} \\
DEHP & $0.98 / 0.023$ & $10.30 / 0.98$ & {$[78]$} \\
DIDP & $0.001 / 0.086$ & $1.97 / 1.40$ & {$[78]$} \\
Fl. & $0.001 / 0.037$ & $0.17 / 0.024$ & {$[78]$} \\
HMMM & $0.07 / 0.039$ & $0.001 / 0.00032$ & {$[78]$} \\
MBT & $0.010 / 0.0011$ & $0.002 / 0.010$ & {$[78]$} \\
NP & $0.0010 / 0.0036$ & $0.021 / 0.031$ & {$[78]$} \\
OP & $0.01 / 0.002$ & $0.001 / 0.015$ & {$[78]$} \\
TT & $0.010 / 0.023$ & $0.0058 / 0.011$ & {[}
\end{tabular}

${ }^{a}$ Concentration in sediment reported in literature in ww and here converted to dw using a factor of 2.6

${ }^{\mathrm{b}}$ Not an estimated value, but modelled by Unice et al. [37]

'Pollutants: BaP Benzo(a) pyrene, BPA Bisphenol A, DEHP Di (2-ethylhexyl) phthalate, DIDP Diisodecyl phthalate, FI. Fluoranthene, HMMM Hexa (methoxymethyl) melamine, MBT Mercaptobenzothiazole, MP Microplastics, NP Nonylphenol, OP 4-tert-octylphenol, TWP Tire Wear Particles, TT Tolyltriazole 
Table 3 PNEC values for microplastics and organic micropollutants in road runoff

\begin{tabular}{|c|c|c|c|}
\hline Pollutant $^{c}$ & PNEC Surface water $(\mu \mathrm{g} / \mathrm{l})$ & PNEC Sediment $\left(\mu \mathrm{g} / \mathrm{kg}_{\mathrm{dw}}\right)$ & Reference \\
\hline$\overline{T W P_{M P}}$ & $0.33^{\mathrm{a}}$ & $100^{a}$ & [65] \\
\hline $\mathrm{BaP}$ & 0.00017 & 1830 & {$[86,87]$} \\
\hline BPA & 1.5 & 63 & [88] \\
\hline DEHP & 1.3 & 100,000 & {$[87,89]$} \\
\hline DIDP & 0.6 & 3300 & Derived $^{\mathrm{b}}$ \\
\hline $\mathrm{Fl}$. & 0.0063 & 2000 & {$[87,90]$} \\
\hline HMMM & 54 & 133 & [91], Derived \\
\hline MBT & 4 & 147 & [92] \\
\hline NP & 0.3 & 4620 & {$[87,93]$} \\
\hline $\mathrm{OP}$ & 0.1 & 1.61 & {$[87,94]$} \\
\hline$\pi$ & 8 & 3 & [95] \\
\hline
\end{tabular}

${ }^{\text {a PNEC values for microplastics (MP) available in the literature were used to represent the PNEC for TWP, i.e. TWP }}$ MP. It should be noted that the PNEC for MP has a limited reliability due to heterogeneity of the tested microplastic considering polymer type, size and shape

${ }^{b}$ PNEC is not available in literature and thus derived using available toxicological data and extrapolation factors (for surface water) or the equilibrium method (for sediment), see Supporting information (Table S6, page 17-22)

'Pollutants: MP Microplastics, BaP Benzo(a) pyrene, BPA Bisphenol A, DEHP Di (2-ethylhexyl) phthalate, DIDP Diisodecyl phthalate, Fl. Fluoranthene, HMMM Hexa (methoxymethyl) melamine, MBT Mercaptobenzothiazole, MP Microplastics, NP Nonylphenol, OP 4-tert-octylphenol, TWP Tire Wear Particles, $T T$ Tolyltriazole

information (Table S14). A PAF of $5 \%$ is considered as the threshold value for environmental protection [64]. The average PAF at PECs in runoff based on measured values reported in literature was above $5 \%$ for $\mathrm{TWP}_{\mathrm{MP}}$, $\mathrm{BaP}, \mathrm{DEHP}$ and fluoranthene (Fig. 3). For surface water, the average PAF only exceeded the threshold for

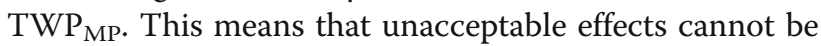
ruled out for these cases.

\section{WET-tests}

WET-tests using bacteria, algae and crustacea were conducted to support the risk assessment, as realistic field samples are tested and combination toxicology as well as yet unidentified substances are covered. The acute luminescence inhibition test with the bacteria Vibrio fischeri showed a slight inhibition for the runoff samples from Germany and Sweden at the highest concentration tested (Table 4). However, this was within the normal variation for this test. Due to the need to suspend the bacteria in culture medium, $45 \%$ was the highest concentration that could be tested. Consequently, effects at higher sample concentrations could not be assessed using this procedure. The surface water sample from a water body near highway A2, the Netherlands, did not show any inhibition at any of the concentrations tested.

The algae growth inhibition test with Raphidocelis subcapitata showed significant dose-related growth inhibition when exposed to the runoff samples (Table 1). The NOEC for runoff from highway E18, Sweden, was established at $42.2 \%$ of the original sample concentration. Even more effect was found for highway A61, Germany, where even at the lowest concentration of $31.6 \%, 84 \%$ effect was observed. A NOEC could not be established. The surface water sample from a water body near highway A2, the Netherlands, did not show statistically significant growth inhibition.

The acute immobilization test with the freshwater crustacean Daphnia magna showed no effects for any of the three samples (Table 4). The highest effect of $10 \%$ was within the normal range of variation for this test. The test results indicate absence of significant toxicity of runoff and surface water samples to the freshwater crustacean Daphnia magna.

\section{Discussion}

We evaluated aquatic ecological risks of TWP and associated road runoff pollutants by combining a prospective risk assessment with a retrospective assessment in order to test whether the risk identified in the prospective assessment could have deleterious effects on aquatic life [62]. We assessed the prospective risk by comparing predicted exposure concentrations of $\mathrm{TWP}_{\mathrm{MP}}$ particles and 10 organic micropollutants with: 1) limits below which no adverse effects of exposure in the aquatic environment are expected (PEC/PNEC ratios), and; 2) by assessing the fraction of species exposed to these concentrations above their NOEC (PAF). This prospective risk differentiates between particle effects $\left(\mathrm{TWP}_{\mathrm{MP}}\right)$ and chemical effects (organic micropollutants). For the retrospective assessment, combined particle and chemical effects were assessed by conducting WET-tests.

\section{Overview of demonstrated effects and risks}

The risk assessment (PEC/PNEC ratios and PAF) shows that for most of the selected substances in surface water and sediment, the risks from road traffic for the 


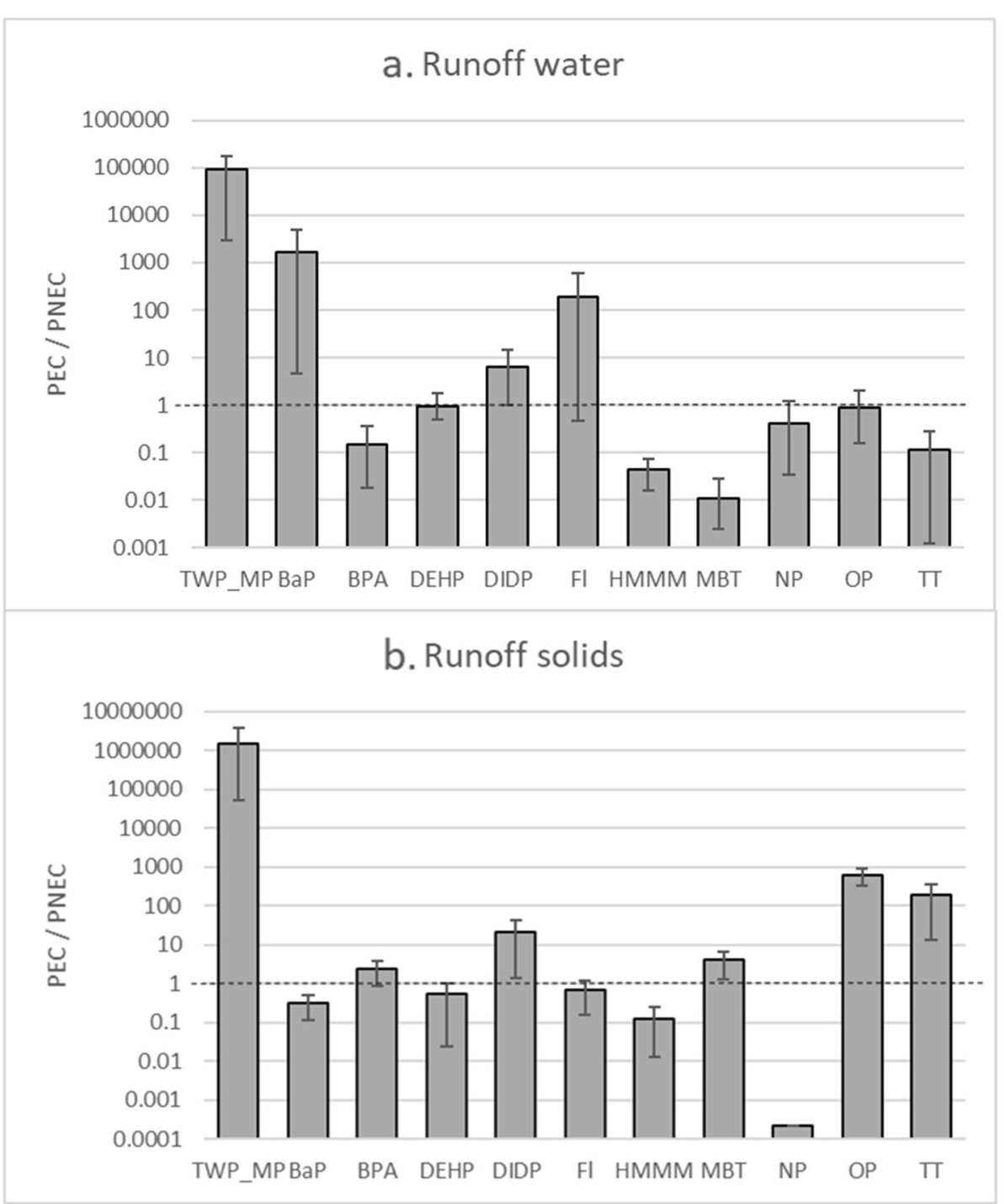

Fig. 1 PEC/PNEC ratios of selected substances in runoff water (a top) and solids (b bottom). Selected substances: tire wear microplastic particles (TWP_MP), benzo(a) pyrene (BaP), bisphenol A (BPA), di (2-ethylhexyl) phthalate (DEHP), diisodecyl phthalate (DIDP), fluoranthene (FI), hexa (methoxymethyl) melamine (HMMM), mercaptobenzothiazole (MBT), nonylphenol (NP), 4-tert-octylphenol (OP) and tolyltriazole (TT). The bar chart shows the average PEC/PNEC based on measured concentrations reported in literature, with the minimum and maximum values represented by the error bars. PEC and PNEC values are provided in Tables 1 and 3, respectively. The dashed horizontal line in the figure marks the threshold indicating unacceptable effects on organisms are likely to occur for PEC/PNEC ratio's higher than 1

investigated European waters are within acceptable limits. However, for a few substances environmental risks have been identified. Based on estimated concentrations in surface water and sediment extrapolated from reported concentrations in runoff, we demonstrate that risks are above threshold values (PEC/PNEC > 1) for $\mathrm{TWP}_{\mathrm{MP}}, \mathrm{BaP}$ and fluoranthene in surface water and for $\mathrm{TWP}_{\mathrm{MP}}$, OP and TT in sediment. However, based on reported empirical data, that is, values reported in literature, risks only exist for $\mathrm{TWP}_{\mathrm{MP}}$ in surface water and $\mathrm{TWP}_{\mathrm{MP}}$ and $\mathrm{TT}$ in sediment. In retrospective, WET-tests of the surface water sample showed no significant toxic effects for bacteria, algae and crustacea.

Concentrations in runoff (water and solids) are much higher than in surface water and sediment and risks (PEC/PNEC $>1$ and/or PAF $>5 \%$ ) cannot be ruled out for most substances. A risk was indicated for $\mathrm{TWP}_{\mathrm{MP}}$, BaP, BPA, DEHP, DIDP, Fluoranthene, MBT, NP, OP and TT in road runoff. WET-tests of road runoff showed no significant toxic effects for bacteria and crustacean, but the algae growth inhibition test showed significant dose-related growth inhibition. The latter confirms the outcome of the prospective risk assessment, i.e. that 


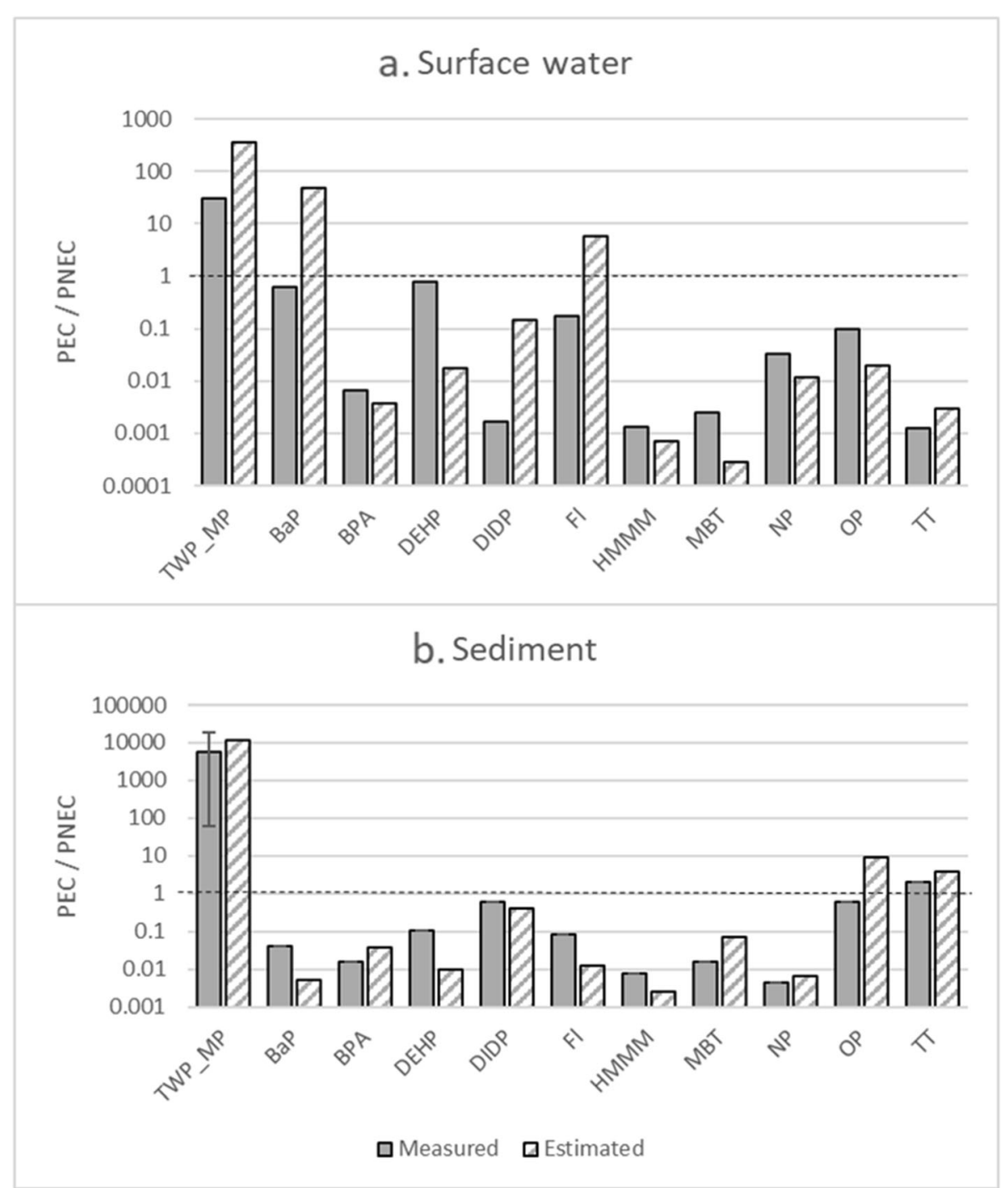

Fig. 2 PEC/PNEC ratios of selected substances in surface water (a top) and sediment (b bottom). Selected substances: tire wear particles (TWP_MP), benzo(a) pyrene (BaP), bisphenol A (BPA), di (2-ethylhexyl) phthalate (DEHP), diisodecyl phthalate (DIDP), fluoranthene (FI), hexa (methoxymethyl) melamine (HMMM), mercaptobenzothiazole (MBT), nonylphenol (NP), 4-tert-octylphenol (OP) and tolyltriazole (TT). PEC and PNEC values are provided in Tables 2 and 3, respectively. PEC values are measured values reported in literature (measured) and extrapolated from values found in literature (estimated). For TWP, the estimated value is the result of modelling [37]. The dashed horizontal line in the figure marks the threshold indicating unacceptable effects on organisms are likely to occur for PEC/PNEC ratio's higher than 1

adverse effects cannot be ruled out for runoff. This could be caused by (the combination of) the substances included in the prospective risk assessment, as well as other runoff components. Other studies have found organic compounds (including a transformation product) and zinc to be largely responsible for the toxicity of TWP leachate $[17,26,35]$. In highway runoff, not only zinc but also copper was found to be the primary cause of toxicity [100]. These main pollutants identified in literature could play a role in the toxicity effects observed by the WET-tests in this study. Concentrations of copper in the runoff samples used for the WET-tests $(8.3$ and $9.1 \mu \mathrm{g} / \mathrm{l}$ in samples from Sweden and Germany, respectively [78]) are above the lowest NOEC value found for bacteria Vibrio fisheri (3.39 $\mu \mathrm{g} \mathrm{Cu} / 1$ [101]), but below the lowest NOEC value found for crustacea Daphnia magna (12.6 $\mu \mathrm{g} \mathrm{Cu} / 1$ [102] and for algae Raphidocelis subcapitata $(15.7 \mu \mathrm{g} \mathrm{Cu} / \mathrm{l}$ [102]). For $R$. subcapitata, however, a NOEC as low as $4.2 \mu \mathrm{g} \mathrm{Cu} / \mathrm{l}$ was suggested under worst case conditions (i.e. considering metal toxicity modifying factors like $\mathrm{pH}$, water hardness and dissolved organic carbon) [103]. For zinc, concentrations in runoff (72 and $230 \mu \mathrm{g} / \mathrm{l}$ in samples from Sweden and Germany, respectively [78]) are well above the lowest NOEC values found for all species used for the WETtests, i.e. V. fisheri $(10 \mu \mathrm{g} \mathrm{Zn/l} \mathrm{[101]),} \mathrm{R.} \mathrm{subcapitata}$ 


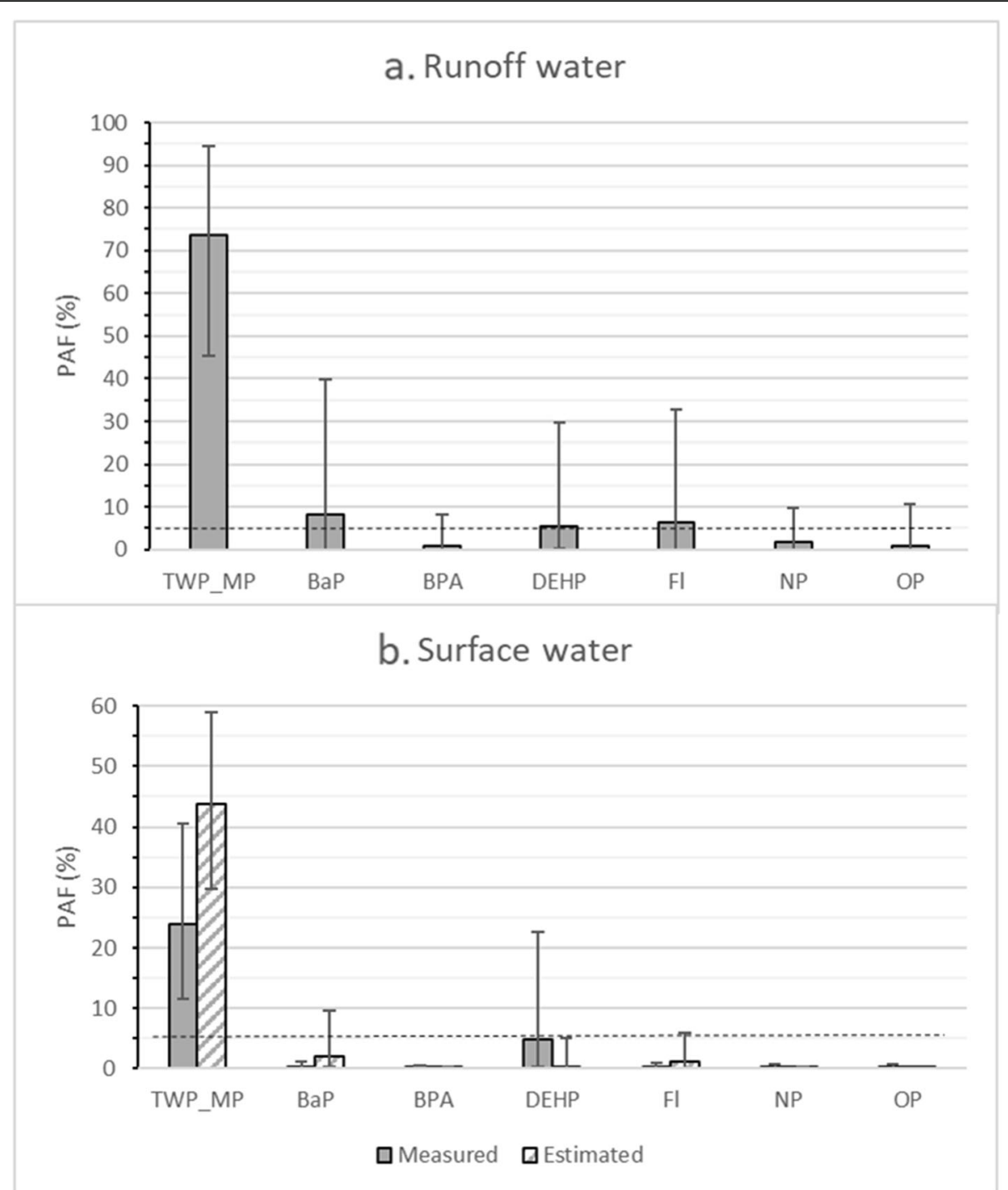

Fig. 3 PAF (\%) of selected substances in runoff water (a top) and surface water (b bottom). Selected substances: TWP_MP (Tire Wear Particles, with PEC represented by TWP and SSD by microplastics), BaP (benzo(a)pyrene), BPA (bisphenol A), DEHP (di (2-ethylhexyl)phthalate) FI (fluoranthene), NP (nonylphenol), OP (4-tert-octylphenol). The PAF (Supporting information, page 31-32) is derived by comparing the PEC (Tables 1 and 2) with the SSD (Supporting information, page 23-30). PAF up to 5\% is considered acceptable [64], as marked by the dotted line in the figure. The bar chart shows the average of the median estimate PAFs ( $50 \%$ confidence), with the error bars representing the lowest value of lower estimates ( $5 \%$ confidence) and the maximum value of upper estimates ( $95 \%$ confidence)

(21 $\mu \mathrm{g} \mathrm{Zn/l} \mathrm{[104])} \mathrm{and} \mathrm{D.} \mathrm{magna} \mathrm{(86 \mu g} \mathrm{Zn/l} \mathrm{[104]),} \mathrm{al-}$ though for $D$. magna only the zinc concentration in the sample from Germany exceeds the NOEC.

\section{Selection of substances}

The selection of substances was focused on WFD priority substances and other substances with hazardous properties. For practical reasons, we limited the selection to 10 substances. Although we addressed relevant pollutants, this does not provide a complete risk profile of all runoff components. A total of 306 organic compounds [29] and heavy metals such as $\mathrm{Zn}, \mathrm{Cu}, \mathrm{Ni}$, and $\mathrm{Cd}$ [31] have been identified in road runoff. A prospective risk assessment accounting for more chemicals could lead to a higher estimation of risk. However, by including the WET-tests of realistic field samples as retrospective assessment, the risk assessment covers all runoff components, including possible unidentified substances.

\section{Exposure assessment}

Estimated PECs in surface water and sediment were based on the highest reported concentration in runoff combined with a dilution factor (1:100) representative for a small surface water body. However, the measured 
Table 4 Summary of WET-test results. Details on the method and results of the WET-tests conducted with runoff samples from highway E18, Sweden and highway A61, Germany and a surface water sample near highway A2, the Netherlands can be found in the technical reports [97-99]. Some endpoints are not available (n.a.), when effect parameters are too low to enable calculation. The concentration is expressed in \% sample in test solution

\begin{tabular}{|c|c|c|c|c|}
\hline \multirow[t]{2}{*}{ Test } & \multirow[t]{2}{*}{ Endpoint } & \multicolumn{3}{|l|}{ Sample } \\
\hline & & Runoff, Germany & Runoff, Sweden & Surface water, the Netherlands \\
\hline \multirow[t]{3}{*}{ Bacteria } & Effect & $8.68 \%$ effect $^{\mathrm{a}}$ at highest conc. (45\%) & $7.06 \%$ effect $^{\mathrm{a}}$ at highest conc. (45\%) & no effects \\
\hline & $\mathrm{EC}_{50}$ & $>45 \%$ & $>45 \%$ & $>45 \%$ \\
\hline & NOEC & n.a. & n.a. & n.a. \\
\hline \multirow[t]{3}{*}{ Algae } & Effect & $84 \%$ effect at lowest conc. (31.6\%) & $35 \%$ effect at highest conc. (100\%) & $6 \%$ effect $^{\mathrm{a}}$ at highest conc. $(100 \%)$ \\
\hline & $\mathrm{EC}_{50}$ & $<31.6 \%$ & $>96 \%$ & $>96 \%$ \\
\hline & NOEC & $<31.6 \%$ & $42.2 \%$ & n.a. \\
\hline \multirow[t]{3}{*}{ Crustacea } & Effect & $0 \%$ effect $^{\mathrm{a}}$ in highest conc. (100\%) & $10 \%$ effect in highest conc. (100\%) & $10 \%$ effect $^{\mathrm{a}}$ in highest conc. (100\%) \\
\hline & $\mathrm{EC}_{50}$ & $>100 \%$ & $>100 \%$ & $>100 \%$ \\
\hline & NOEC & n.a. & n.a. & n.a. \\
\hline
\end{tabular}

${ }^{a}$ Within the normal range of variation for this test

PECs exceeded the estimated PECs in many cases (i.e. for all substances in either surface water and/or sediment). Thus, the estimated concentrations do not represent a worst case exposure scenario. This could be caused by the applied dilution factor, assuming surface water containing $1 \%$ road runoff. This dilution has however been applied by others to estimate road runoff concentrations in standing waters [105]. However, for small static water bodies receiving relatively high volumes of runoff, e.g. through splash and spray, dilution may be less. For such water bodies, undiluted runoff concentrations better represent a worst case exposure scenario. Other factors are the fact that the number of measurements in literature is limited for these pollutants (therewith hampering a representative comparison) and the input of other emissions besides traffic related sources. For example, other main sources of phthalates (DEHP, DIDP) and NP are roofing and cladding and flexible PVC $[68,106]$, while OP, BPA, HMMM and MBT are also released from industrial and/or residential wastewater [84, 107-109].

The PEC values of TWP were based on reported values in literature, which were based on measurements [41, 78-80] and modelling [37]. TWP concentrations in runoff were measured in the water phase at values of $975 \mu \mathrm{g} / \mathrm{l}$ and 58,500 $\mu \mathrm{g} / \mathrm{l}[78]$ and in the solid phase at values of $13,000 \mathrm{mg} / \mathrm{kg}_{\text {dry }}$ weight (dw) $, 150,000 \mathrm{mg} / \mathrm{kg}_{\mathrm{dw}}$ [78], $2000 \mathrm{mg} / \mathrm{kg}_{\text {wet weight (ww) }}, 150,000 \mathrm{mg} / \mathrm{kg}_{\mathrm{ww}}$ [79] and $70,000 \mathrm{mg} / \mathrm{kg}_{\mathrm{ww}}$ [80]. Liu et al. [110] have measured microplastics in runoff excluding TWP and reported concentrations of $0.231(0.085-1.143) \mu \mathrm{g} / \mathrm{l}$, which were not used as PECs in our study. These concentrations of microplastics without TWP are much lower than those measured of TWP, which is to be expected considering runoff as a main pathway of TWP entering the aquatic environment and TWP being a major source of microplastics [3-6]. In surface water, TWP were measured at $6 \mu \mathrm{g} / \mathrm{l}$ [78] and $10 \mu \mathrm{g} / \mathrm{l}$ [41] and modelled at $27 \mu \mathrm{g} / \mathrm{l}$ (annual average with ranges between 3.7 and $120 \mu \mathrm{g} / \mathrm{l}$ [37]). In sediment, TWP were measured at $2.3 \mathrm{mg} / \mathrm{kg}_{\mathrm{ww}}$ [41], $300 \mathrm{mg} / \mathrm{kg}_{\mathrm{dw}}$ [78] and $730 \mathrm{mg} / \mathrm{kg}_{\mathrm{ww}}$ [79]. A review of microplastic particle concentrations in river and lake water, groundwater, tap water, bottled drinking water and wastewater in Asia, Australia, Europe and North America found concentrations to range from $1 \times 10^{-2}$ to $10^{8}$ particles $/ \mathrm{m}^{3}$ [111]. Assuming a particle weight of $12.5 \mu \mathrm{g}$ per particle [112], this corresponds to a concentration of $1.25 \times 10^{-4}$ to $10^{6} \mu \mathrm{g} / \mathrm{l}$. Our TWP PECs fall within this broad range including those of river and lake water.

\section{Effect assessment}

Effect data for TWP were limited and therefore we used effect data for microplastics as a proxy for physical particle effects. Given that particle-volume based 'food dilution' has been found to be the primary effect mechanism for low-caloric particles such as TWP and microplastics, this approach is legitimate [60,61]. Preferably effect data for TWP should be based on real-world concentrations and material of TWP. However this is very scarcely available. Most effect data originated from experiments with leachates of whole tires or artificially produced tire wear (see compilation by Wagner et al. [8]) and some experiments with TWP dispersions [43, 44] and spiked sediments, e.g. Redondo-Hasselerharm et al. [42]. Novel data are presented here for the WET-test with three aquatic species exposed to environmental samples taken from road runoff and surface water near highways. However, more ecotoxicity testing is required to provide sufficient insight in the potential effects and concomitant 
risk of TWP in surface water. The main approach presented here is a risk assessment of selected substances as components of TWP based on published effect data on the ecotoxicity of single substances and microplastics. The chronic effect values used for the SSD were based on NOECs and $\mathrm{EC}_{0}$ to $\mathrm{EC}_{10}$ values. This approach complies to the EU TGD [64]. Research has demonstrated that using either $\mathrm{EC}_{10}$ or NOEC values does not largely affect the results of effect assessment [113]. For BaP, OP and DEHP the number of chronic effect values did not meet the requirements for SSD derivation so acute effect values were also included (i.e. $\mathrm{EC}_{50}$ and $\mathrm{LC}_{50}$ values). $\mathrm{A}$ pragmatic acute to chronic ratio of 10 [69] was used to extrapolate chronic toxicity levels from acute toxicity values for the chemical substances. A more refined approach is to apply extrapolation factors depending on the exposure duration of the toxicity test, as applied for microplastic following Besseling et al. [65], Adam et al. [66] and Koelmans et al. [61].

The effect values for the SSD approach were based on exposure via the water phase only as sediment toxicity data is limited and the SSD approach requires at least 10 effect values. More toxicity data for sediment organisms are necessary in order to derive an SSD for TWP and related substances. Recently, standardized protocols for bioassays with tire particles are developed [42, 60], enabling the generation of sediment toxicity data with maximum applicability for risk assessments. With increasing data availability, a probabilistic risk assessment for exposure via sediment and solids could be possible. This is especially important considering microplastic particles with a density higher as well as lower than water can settle and be buried in the sediment [114], making sediments act as a sink for TWP $[8,10]$.

The software used for SSD derivation, ETX 2.1, applies a cumulative log-normal distribution, where sensitivity values for species are fitted to a logarithmic scale. The data is tested for normality by three statistical tests: the Anderson-Darling, the Kolmogorov-Smirnov and the Cramer von Mises test. SSDs should not be applied on a dataset when statistical tests for log normal distribution fail $[64,115]$. This criterion has been partly applied for the underlying risk assessment. The KolmogorovSmirnov test for normality was accepted for all substances at a significance level of 0.005. The AndersonDarling and Cramer von Mises goodness-of-fit tests were accepted for most substances but rejected for fluoranthene and NP. This adds uncertainty to the PAF for fluoranthene and NP. For BPA, the dataset was adjusted in order to achieve better results with respect to the normal distribution [64, 115]. As the type of effect (e.g. mortality, morphology, development, reproduction) has influence on the effect concentration and therewith adds to the uncertainty for species sensitivity, the dataset for
BPA was limited to only include mortality effects. This dataset was found to be normally distributed (all tests were accepted), whereas the dataset based on all type of effects had a low probability of normal distribution (all tests failed).

\section{Risk characterization}

The risk assessment (i.e. PEC/PNEC ratio and PAF) applied in this study only considers individual substances and not the combined toxic pressure of multiple substances in runoff. Combined toxicity can be addressed by applying the multi species (ms) PAF $[63,116]$. This is not elaborated in this study. However, the WET-tests cover combined toxicity and these showed significant toxic effects for algae when exposed to road runoff, whereas bacteria and crustacea showed no significant toxic effects. The risk assessment for runoff indicates potential effects of $\mathrm{TWP}_{\mathrm{MP}}, \mathrm{BaP}$, fluoranthene, OP, DIDP and DEHP. The cause of the toxicity cannot fully be explained by the underlying risk assessment as none of the substances are more toxic to algae compared to other species (i.e. algae are not the most sensitive species group for the selected substances, see Tables S6 and S7). This suggests that the observed toxicity is caused by one or more currently unidentified toxicants. Additional approaches, such as the TIE (Toxicity Identification and Evaluation) approach, would be required in order to get insight in the type of compounds, or even to identify the individual compound(s) responsible for the toxicity in the runoff water.

\section{Risk of TWP}

To assess the risk of TWP, environmental concentrations of TWP need to be compared to effect values of TWP. As aquatic effect data of microplastic particles from tires are scarce [43, 44, 117], we used microplastics in general as a proxy to assess the particle component of the effect of $\mathrm{TWP}_{\mathrm{MP}}$. This is considered a limitation because consistent risk assessment for microplastic particles requires alignment of exposure and effect data, i.e. whatever metric or unit is used to characterize exposure also is used for the effect assessment [61]. Koelmans et al. (2020) propose and test rescaling methods for exposure and effect assessment. In future, when exposure and effect data of TWP is sufficiently available, methods to correct for the differences in particle types and size ranges [61] could be applied to improve the risk assessment. The PNEC and SSD used in this study are based on data for a wide range of microplastics generated by Adam et al. [66] and Besseling et al. [65]. The "all-inclusive" SSD [65] can be considered as a proxy for TWP because the size and density of the particles used for the SSD $\left(0.1\right.$ to $600 \mu \mathrm{m}[65,66]$ and 0.78 to $1.39 \mathrm{~g} / \mathrm{cm}^{3}[118$, 119] are covering those of car tire particles $(4 \mu \mathrm{m}$ to 
$350 \mu \mathrm{m}$ [14] and $1.2 \mathrm{~g} / \mathrm{cm}^{3}$ [79]). Recently, RedondoHasselerharm et al. [42] studied TWP toxicity to four benthic species and found that neither the particles themselves nor any of the associated chemicals were toxic at tire particle concentrations up to $10 \%$ sediment dry weight. That concentration is far (factor $10^{6}$ ) above the $\mathrm{PNEC}_{\text {sediment }}$ for microplastics $(0.1 \mathrm{mg} / \mathrm{kg}$ dry weight [65]) we used in our study as representative for species sensitivity to TWP, in line with our approach for the

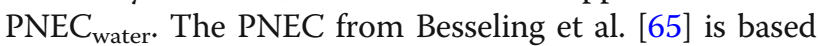
on the lowest effect value from six benthic species together with a safety factor of 1000 to derive a PNEC, whereas Redondo-Hasselerharm et al. [42] used four benthic species and no safety factor because a PNEC was not derived. Considering this safety factor, the difference is reduced to a factor $10^{3}$. This suggests that we may have overestimated the risk posed by the tire wear particles in sediment and solids by using the conservative $\mathrm{PNEC}_{\text {sediment }}$ for microplastics from Besseling et al. [65]. The same applies for the water phase, as recent studies $[43,120]$ observed effects of TWP suspensions at far higher concentration levels (NOEC is $0.26 \mathrm{~g} / \mathrm{l}$ for Hyalella Azteca [43]) than the $\mathrm{PNEC}_{\text {water }}$ used in this study $(0.33 \mu \mathrm{g} / \mathrm{l}[65])$.

The underlying preliminary risk assessment indicated that unacceptable effects of microplastics from traffic related sources are likely to occur. PEC/PNEC ratio's and PAF exceeded acceptable levels for all locations and matrices. For runoff, this might be expected, as this can be considered as the undiluted and untreated effluent from traffic. Since the environmental risk from microplastics in runoff has not yet been addressed in the scientific literature, we cannot compare our findings with other studies. In surface water and sediment, however, this is a different case. On the basis of evidence published to date, effects of microplastic at a population level appear unlikely [5], although for some hotspots, effects cannot be excluded [61, 65, 66]. As the scope of the underlying risk assessment is focused on hotspots, by extrapolating the highest reported concentrations in literature as estimated PEC and measurements in samples taken in close proximity to the source [78] as measured PEC, our findings are not contradictory. However, PEC/PNEC ratio's and PAF estimated in the risk assessment are relatively high compared to Adam et al. [66] and Besseling et al. [65]. As risk is determined by the comparison of environmental exposure (PEC) with a measure of sensitivity (PNEC or SSD (via PAF)), this could be the result of higher exposure, higher sensitivity, or both. Comparing the PNEC for microplastic used in this study $(0.33 \mu \mathrm{g} / \mathrm{L}$, corresponding to a $5 \%$ hazard concentration $\left(\mathrm{HC}_{5}\right)$ of $1.65 \mu \mathrm{g} / \mathrm{L}$ or 1015 particles/L [65]) with other PNEC and $\mathrm{HC}_{5}$ values available in literature $\left(\mathrm{HC}_{5}\right.$ of 3500 particles/L [121, 122]; $\mathrm{HC}_{5}$ of 3214
particles/L [123]; PNEC of $0.042 \mu \mathrm{g} / \mathrm{L}$ or 740 particles/L [66]; PNEC of $0.14 \mu \mathrm{g} / \mathrm{L}$ or 71.6 particles/L [124]; and $\mathrm{HC}_{5}$ of 251 particles/L or 75.6 particles/L when corrected for the differences in size ranges, bioavailability and polydispersity [61]) shows that the PNEC is within the range of literature values. The SSD used in the present study (see Supporting information, page 23) is based on NOEC values from Adam et al. [66] and Besseling et al. [65] combined, and is thus also comparable to the SSDs in their studies. Besseling et al. [65] uses a freshwater PEC of 0.14 particles/L, corresponding to $1.77 \mu \mathrm{g} / \mathrm{L}$ when assuming a particle weight of $12.5 \mu \mathrm{g}$ [112]. Adam et al. [66] used PECs mostly between $10^{-2}$ and $10^{4}$ particles $/ \mathrm{m}^{3}$, corresponding to a range between $1.2510^{-4}$ and $12.5 \mu \mathrm{g} / \mathrm{L}$. The PECs used in this study for TWP in surface water $(6 \mu \mathrm{g} / \mathrm{L}$ [78] and $10 \mu \mathrm{g} / \mathrm{L}$ [41]) are higher than PECs for microplastics used by Besseling et al. [65] but comparable with maximum values for microplastics used by Adam et al. [66].

\section{Conclusions}

This study provides opportunities to protect the quality of European waters from road runoff pollution, focusing on car tire microplastic particles, WFD priority substances and other hazardous substances. It emphasizes the relevance of addressing risks of microplastic particles originating from car tires. Results indicate that TWP occur in relatively high concentrations compared to microplastics in general and that the corresponding risk of TWP is above threshold levels. Because TWP exists both as anthropogenic particulates and as a source of a suite of chemicals, providing a risk assessment is challenging. This study provides a first risk assessment posed by particle effects $\left(\mathrm{TWP}_{\mathrm{MP}}\right)$ as well as risks posed by chemical effects (organic micropollutants). Additional research is required to further address the risks of TWP, e.g. toxicity testing for environmentally realistic TWP material and aligning exposure and effect data. Furthermore, the risks of some micropollutants (TT, DIDP, MBT and HMMM) could be further investigated in future when more effect data might be available, as well as addressing the risks of exposure via sediment and identifying the main contributors to the toxicity of road runoff to algae.

\footnotetext{
Abbreviations

BaP: Benzo(a)pyrene; BPA: Bisphenol A; DEHP: Di (2-ethylhexyl)phthalate; DIDP: Diisodecyl phthalate; EC: Effect concentration at which $x \%$ effect (mortality, inhibition of growth, reproduction, etc.) is observed compared to the control group; EQS: Environmental Quality Standard; FI: Fluoranthene; $\mathrm{HC}_{5}$ : Hazardous Concentration for 5\% of the species; HMMM: Hexa (methoxymethyl)melamine; LC So: Lethal Concentration 50\%;

MBT: Mercaptobenzothiazole; ms PAF: Multi species PAF; NOEC: No Observed Effect Concentration; NP: Nonylphenol; OP: 4-tert-octylphenol;

PAF: Potentially Affected Fraction of species; PEC: Predicted Environmental Concentration; PNEC: Predicted No Effect Concentration; SSD: Species Sensitivity Distribution; TIE: Toxicity Identification and Evaluation; TRWP: Tire
} 
and road wear particles; TT: Tolyltriazole; TWP: Tire wear particles, i.e. microplastic particles originating from car tires; TWP $\mathrm{MP}$ : Tire Wear Particles Microplastic, where exposure is represented by TWP and effect by microplastics; WET: Whole Effluent Toxicity; WFD: Water Framework Directive

\section{Supplementary Information}

The online version contains supplementary material available at https://doi. org/10.1186/s43591-021-00008-w.

\section{Additional file 1}

\section{Acknowledgments}

We gratefully acknowledge the financial and technical support of the CEDR and the CEDR Programme Executive Board.

\section{Authors' contributions}

The manuscript was written through contributions of all authors. All authors have given approval to the final version of the manuscript.

\section{Funding}

This study is a part of the Conference of European Directors of Roads (CEDR) Transnational Research Programme Call 2016 Water Quality: Environmentally Sustainable Roads (funded by Austria, Finland, Germany, Ireland, Netherlands, Norway and Sweden).

\section{Availability of data and materials}

All data generated or analyzed during this study are included in this published article and its Supporting information file. The Supporting information file contains information on: 1) WET-tests; 2) organic micropollutants and sources released from traffic and roads; 3) selection of substances for the risk assessment; 4) PEC values; 5) PNEC values (including equilibrium partitioning); 6) SSDs; 7) PAF values; 8) effect values for microplastics and selected organic micropollutants.

\section{Declarations}

\section{Competing interests}

The authors declare that they have no competing interests.

\section{Author details}

'Wageningen Marine Research, Ankerpark 27, Den Helder 1781 AG, the Netherlands. ${ }^{2}$ Aquatic Ecology and Water Quality Management Group, Wageningen University, Wageningen, Netherlands. ${ }^{3}$ TNO, Circular Economy and Environment, Princetonlaan 6, Utrecht 3584 CB, the Netherlands.

\section{Received: 29 December 2020 Accepted: 27 May 2021}

\section{Published online: 02 July 2021}

\section{References}

1. SAPEA. A scientific perspective on microplastics in nature and society. Berlin: 2019. https://doi.org/10.26356/microplastics.

2. Akdogan Z, Guven B. Microplastics in the environment: a critical review of current understanding and identification of future research needs. Environ Pollut. 2019;254:113011 Available from: https://linkinghub.elsevier.com/ retrieve/pii/S0269749119302039.

3. Siegfried M, Koelmans AA, Besseling E, Kroeze C. Export of microplastics from land to sea. a modelling approach. Water Res. 2017;127:249-57. https://doi.org/10.1016/j.watres.2017.10.011.

4. Kole PJ, Löhr AJ, Van Belleghem FGAJ, Ragas AMJ. Wear and tear of tyres: a stealthy source of microplastics in the environment. Int J Environ Res Public Health. 2017:14(10):1265

5. Hann S, Sherrington C, Jamieson O, Hickman M, Kershaw P, Bapasola A, et al. Investigating options for reducing releases in the aquatic environment of microplastics emitted by (but not intentionally added in) products interim report. Report for DG Env EC. 2018.

6. Verschoor A, de Poorter L, Dröge R, Kuenen J, de Valk E. Emission of microplastics and potential mitigation measures: abrasive cleaning agents, paints and tyre wear. Bilthoven: National Institute for Public Health and the Environment; 2016.
7. Baensch-Baltruschat B, Kocher B, Kochleus C, Stock F, Reifferscheid G. Tyre and road wear particles - a calculation of generation, transport and release to water and soil with special regard to German roads. Sci Total Environ. 2021;752:141939. https://doi.org/10.1016/j.scitotenv.2020.141939.

8. Wagner $S$, Hüffer T, Klöckner P, Wehrhahn M, Hofmann T, Reemtsma T. Tire wear particles in the aquatic environment - a review on generation, analysis, occurrence, fate and effects. Water Res. 2018;139(March):83-100. https://doi.org/10.1016/j.watres.2018.03.051.

9. Panko JM, Kreider ML, McAtee BL, Marwood C. Chronic toxicity of tire and road wear particles to water- and sediment-dwelling organisms. Ecotoxicology. 2013;22(1):13-21. https://doi.org/10.1007/s10646-012-0998-9.

10. Wik A, Dave G. Occurrence and effects of tire wear particles in the environment - a critical review and an initial risk assessment. Environ Pollut. 2009;157(1):1-11. https://doi.org/10.1016/j.envpol.2008.09.028.

11. Sommer F, Dietze V, Baum A, Sauer J, Gilge S, Maschowski C, et al. Tire abrasion as a major source of microplastics in the environment. Aerosol Air Qual Res. 2018;(1991):2014-28 Available from: http://www.aaqr.org/doi/10.42 09/aaqr.2018.03.0099.

12. Baensch-Baltruschat B, Kocher B, Stock F, Reifferscheid G. Tyre and road wear particles (TRWP) - A review of generation, properties, emissions, human health risk, ecotoxicity, and fate in the environment. Sci Total Environ. Elsevier B.V. 2020;733:37823.

13. Halle LL, Palmqvist A, Kampmann K, Khan FR. Ecotoxicology of micronized tire rubber: past, present and future considerations. Sci Total Environ. Elsevier B.V. 2020;706:135694.

14. Kreider ML, Panko JM, McAtee BL, Sweet LI, Finley BL. Physical and chemical characterization of tire-related particles: comparison of particles generated using different methodologies. Sci Total Environ. 2010;408(3):652-9. https:// doi.org/10.1016/j.scitotenv.2009.10.016.

15. Marwood C, McAtee B, Kreider M, Ogle RS, Finley B, Sweet L, et al. Acute aquatic toxicity of tire and road wear particles to alga, daphnid, and fish. Ecotoxicology. 2011;20(8):2079-89. https://doi.org/10.1007/s10646-011-0750$x$.

16. Unice KM, Kreider ML, Panko JM Comparison of tire and road wear particle concentrations in sediment for watersheds in France, Japan, and the United States by quantitative pyrolysis GC/MS analysis. Environ Sci Technol. 2013; 47(15):8138-47. https://doi.org/10.1021/es400871j.

17. Turner A, Rice L. Toxicity of tire wear particle leachate to the marine macroalga, Ulva lactuca. Environ Pollut. 2010;158(12):3650-4. https://doi. org/10.1016/j.envpol.2010.08.001

18. Zhang J, Hua P, Krebs P. The chemical fractionation and potential source identification of $\mathrm{Cu}, \mathrm{Zn}$ and $\mathrm{Cd}$ on urban watershed. Water Sci Technol. 2015;72(8):1428-36. https://doi.org/10.2166/wst.2015.355.

19. Rose S, Shea JA. Chapter 6 Environmental geochemistry of trace metal pollution in urban watersheds. In: Developments in environmental science, vol. 5; 2007. p. 99-131

20. Aatmeeyata, Sharma M. Contribution of traffic-generated nonexhaust PAHs, elemental carbon, and organic carbon emission to air and urban runoff pollution. J Environ Eng. 2010;136(12):1447-50 Available from: https://a scelibrary.org/doi/abs/10.1061/\%28ASCE\%29EE.1943-7870.0000274. Cited 2021 Mar 2.

21. Day KE, Holtze KE, Metcalfe-Smith JL, Bishop CT, Dutka BJ. Toxicity of leachate from automobile tires to aquatic biota. Chemosphere. 1993;27(4): 665-75. https://doi.org/10.1016/0045-6535(93)90100-J.

22. Stephensen E, Adolfsson-Erici M, Celander M, Hulander M, Parkkonen J, Hegelund T, et al. Biomarker responses and chemical analyses in fish indicate leakage of polycyclic aromatic hydrocarbons and other compounds from car tire rubber. Environ Toxicol Chem. 2003;22(12):2926-31. https://doi. org/10.1897/02-444

23. Wik A, Dave G. Environmental labeling of car tires-toxicity to Daphnia magna can be used as a screening method. Chemosphere. 2005:58(5):64551. https://doi.org/10.1016/j.chemosphere.2004.08.103.

24. Wik A, Dave G. Acute toxicity of leachates of tire wear material to Daphnia magna-variability and toxic components. Chemosphere. 2006;64(10):177784. https://doi.org/10.1016/j.chemosphere.2005.12.045.

25. Wik A. When the rubber meets the road - ecotoxicological hazard and risk assessment of tire wear particles. 2008. Available from: http://gupea.ub.gu. se/handle/2077/17762\%5Cn http://gupea.ub.gu.se/bitstream/2077/17762/1/ gupea_2077_17762_1.pdf\%5Cn https://gupea.ub.gu.se/handle/2077/17762

26. Wik A, Nilsson E, Källqvist T, Tobiesen A, Dave G. Toxicity assessment of sequential leachates of tire powder using a battery of toxicity tests and 
toxicity identification evaluations. Chem Int. 2009;77(7):922-7. https://doi. org/10.1016/j.chemosphere.2009.08.034.

27. Petrucci G, Gromaire MC, Shorshani MF, Chebbo G. Nonpoint source pollution of urban stormwater runoff: a methodology for source analysis. Environ Sci Pollut Res. 2014;21(17):10225-42. https://doi.org/10.1007/s11356014-2845-4.

28. Mohammed T, Loganathan P, Kinsela A, Vigneswaran S, Kandasamy J. Enrichment, inter-relationship, and fractionation of heavy metals in roaddeposited sediments of Sydney, Australia. Soil Res. 2012;50(3):229-38. https://doi.org/10.1071/SR12010.

29. Markiewicz A, Björklund K, Eriksson E, Kalmykova Y, Strömvall AM, Siopi A. Emissions of organic pollutants from traffic and roads: priority pollutants selection and substance flow analysis. Sci Total Environ. 2017;580:1162-74. https://doi.org/10.1016/j.scitotenv.2016.12.074.

30. Lygren E, Gjessing E, Berglind L. Pollution transport from a highway. Sci Total Environ. 1984;33(1-4):147-59. https://doi.org/10.1016/0048-9697(84 )90389-9.

31. Huber M, Welker A, Helmreich B. Critical review of heavy metal pollution of traffic area runoff: occurrence, influencing factors, and partitioning. Sci Total Environ. 2016;541:895-919 Available from: https://inkinghub.elsevier.com/ retrieve/pii/S0048969715306938. Cited 2021 Mar 2.

32. Evans JJ. Rubber tire leachates in the aquatic environment. Rev Environ Contam Toxicol. 1997;151:67-115 Available from: http://www.ncbi.nlm.nih. gov/pubmed/9216257.

33. Degaffe FS, Turner A. Leaching of zinc from tire wear particles under simulated estuarine conditions. Chemosphere. 2011;85(5):738-43. https:// doi.org/10.1016/j.chemosphere.2011.06.047.

34. Blok J. Environmental exposure of road borders to zinc. Sci Total Environ. 2005;348(1-3):173-90. https://doi.org/10.1016/j.scitotenv.2004.12.073.

35. Tian Z, Zhao H, Peter KT, Gonzalez M, Wetzel J, Wu C, et al. A ubiquitous tire rubber-derived chemical induces acute mortality in coho salmon. Science (80- ). 2021;371(6525):185-9.

36. Capolupo M, Sørensen L, Jayasena KDR, Booth AM, Fabbri E. Chemical composition and ecotoxicity of plastic and car tire rubber leachates to aquatic organisms. Water Res. 2020;169:115270. https://doi.org/10.1016/j.wa tres.2019.115270.

37. Unice KM, Weeber MP, Abramson MM, Reid RCD, van Gils JAG, Markus AA, et al. Characterizing export of land-based microplastics to the estuary - part I: application of integrated geospatial microplastic transport models to assess tire and road wear particles in the Seine watershed. Sci Total Environ. 2019;646:1639-49. https://doi.org/10.1016/j.scitotenv.2018.07.368.

38. Knight $\mathrm{L}$, Parker-Jurd FNF, Al-Sid-Cheikh M, Thompson RC. Tyre wear particles: an abundant yet widely unreported microplastic? Environ Sci Pollut Res. 2020;27(15):18345-54. https://doi.org/10.1007/s11356-020-081 87-4 Cited 2020 Dec 18.

39. Wik A, Lycken J, Dave G. Sediment quality assessment of road runoff detention systems in Sweden and the potential contribution of tire wear. Water Air Soil Pollut. 2008;194(1):301-14. https://doi.org/10.1007/s11270008-9718-8.

40. Ziajahromi S, Drapper D, Hornbuckle A, Rintoul L, Leusch FDL. Microplastic pollution in a stormwater floating treatment wetland: detection of tyre particles in sediment. Sci Total Environ. 2020;713:136356 Available from: https://linkinghub.elsevier.com/retrieve/pii/S0048969719363521. Cited 2020 May 27.

41. Leads RR, Weinstein JE. Occurrence of tire wear particles and other microplastics within the tributaries of the Charleston Harbor Estuary, South Carolina, USA. Mar Pollut Bull. 2019;145:569-82. https://doi.org/10.1016/j.ma rpolbul.2019.06.061.

42. Redondo-Hasselerharm PE, De Ruijter VN, Mintenig SM, Verschoor A, Koelmans AA, Redondo Hasselerharm PE, et al. Ingestion and chronic effects of car tire tread particles on freshwater benthic macroinvertebrates. Environ Sci Technol. 2018:52(23):13986-94. https://doi.org/10.1021/acs.est.8b05035.

43. Halle LL, Palmqvist A, Kampmann K, Jensen A, Hansen T, Khan FR. Tire wear particle and leachate exposures from a pristine and road-worn tire to Hyalella azteca: comparison of chemical content and biological effects. Aquat Toxicol. 2021;232:105769. https://doi.org/10.1016/.aquatox.2021.1 05769.

44. Khan FR, Halle LL, Palmqvist A. Acute and long-term toxicity of micronized car tire wear particles to Hyalella azteca. Aquat Toxicol. 2019;213(February): 105216 Available from: https://linkinghub.elsevier.com/retrieve/pii/S016644 $5 \times 19301729$.
45. Kukutschova J, Moravec P, Tomasek V, Matejka V, Smolik J, Schwarz J, et al. On airborne nano/micro-sized wear particles released from low-metallic automotive brakes. Environ Pollut. 2011;159(4):998-1006. https://doi.org/10.1 016/j.envpol.2010.11.036

46. Kumata H, Yamada J, Masuda K, Takada H, Sato Y, Sakurai T, et al. Benzothiazolamines as tire-derived molecular markers: Sorptive behavior in street runoff and application to source apportioning. Environ Sci Technol. 2002;36(4):702-8. https://doi.org/10.1021/es0155229.

47. Lassen C, Hansen SF, Magnusson K, Norén F, Hartmann NIB, Jensen PR, et al. Microplastics occurrence, effects and sources of releases to the environment in Denmark. Copenhagen: Danish Environmental Protection Agency; 2015.

48. Rogge WF, Hildemann LM, Mazurek MA, Cass G, Simoneit BRT. Sources of fine organic aerosol .3. road dust, tire debris, and organometallic brake lining dust - roads as sources and sinks. Environ Sci Technol. 1993;27(9): 1892-904. https://doi.org/10.1021/es00046a019.

49. Staples C, Dorn P, Klecka G, O'Block S, Harris L. A review of the environmental fate, effects, and exposures of bisphenol A. Chemosphere. 1998;36(10):2149-73. https://doi.org/10.1016/S0045-6535(97)10133-3.

50. Thorpe A, Harrison RM. Sources and properties of non-exhaust particulate matter from road traffic: a review. Sci Total Environ. 2008;400(1-3):270-82. https://doi.org/10.1016/j.scitotenv.2008.06.007.

51. Wahid SMS. Automotive brake wear: a review. Environ Sci Pollut Res. 2018; 25(1):174-80. https://doi.org/10.1007/s11356-017-0463-7.

52. Andersson Å, Sörme L. Substansflödesanalys - av alkylfenoler och alkylfenoletoxilater i Stockholms stad 2004 (substance flow analysis - of alkylphenols and alkylphenol in the city of Stockholm 2004). issn: 16539168; 2004.

53. Aznar A, Caprari J, Meda J, Slutzky O. Study of formulation variables of thermoplastic reflecting materials for traffic marking. J Coatings Technol. 1997;69(868):33-8. https://doi.org/10.1007/BF02696247.

54. Chan D, Stachowiak G. Review of automotive brake friction materials. Proceedings of the Institution of Mechanical Engineers Part D-9. J Automob Eng. 2004;218(D9):953-66. https://doi.org/10.1243/0954407041856773.

55. Cruz M, Klein A, Steiner V. Sustainability assessment of road marking systems. 6th Transport Research Arena April 18-21, 2016. Transp Res Procedia. 2016;14(2016):869-75. https://doi.org/10.1016/j.trpro.2016.05.035.

56. Filip $P$, Weiss $Z$, Rafaja D. On friction layer formation in polymer matrix composite materials for brake applications. Wear. 2002;252(3-4):189-98. https://doi.org/10.1016/S0043-1648(01)00873-0.

57. Grigoratos T, Martini G. Non-exhaust traffic related emissions - brake and tyre wear PM. Luxembourg: Publications Office of the European Union; 2014.

58. Grung M, Vikan H, Hertel-Aas T, Meland S, Thomas KV, Ranneklev S. Roads and motorized transport as major sources of priority substances? A data register study. -part A-current issues. J Toxicol Environ Health. 2017;80(1618):1031-47. https://doi.org/10.1080/15287394.2017.1352206.

59. Horton AA, Svendsen C, Williams RJ, Spurgeon DJ, Lahive E. Large microplastic particles in sediments of tributaries of the river thames, UK abundance, sources and methods for effective quantification. Mar Pollut Bull. 2017;114(1):218-26. https://doi.org/10.1016/j.marpolbul.2016.09.004.

60. de Ruijter VN, Redondo-Hasselerharm PE, Gouin T, Koelmans AA. Quality criteria for microplastic effect studies in the context of risk assessment: a critical review. Environ Sci Technol. 2020;54(19):11692-705. https://doi.org/1 0.1021/acs.est.0c03057 Cited 2020 Oct 30.

61. Koelmans AA, Redondo-Hasselerharm PE, Mohamed Nor NH, Kooi M. Solving the nonalignment of methods and approaches used in microplastic research to consistently characterize risk. Environ Sci Technol. 2020;54(19): 12307-15. https://doi.org/10.1021/acs.est.0c02982 Cited 2020 Dec 15.

62. Diamond J, Altenburger R, Coors A, Dyer SD, Focazio M, Kidd K, et al. Use of prospective and retrospective risk assessment methods that simplify chemical mixtures associated with treated domestic wastewater discharges. Environ Toxicol Chem. 2018;37(3):690-702. https://doi.org/10.1002/etc.4013.

63. Posthuma $L$, de Zwart D. Species sensitivity distributions. In: Wexler $P$, editor. Encyclopedia of toxicology. 3rd ed. San Diego: Elsevier/Academic Press; 2014. p. 363-8. https://doi.org/10.1016/B978-0-12-386454-3.00580-7.

64. European Commission. Technical guidance document on risk assessment. Part II. Luxembourg: Office for official publications of the European Communities; 2003. p. 337. Available from: https://echa.europa.eu/ documents/10162/16960216/tgdpart2_2ed_en.pdf

65. Besseling E, Redondo-Hasselerharm P, Foekema EM, Koelmans AA. Quantifying ecological risks of aquatic micro- and nanoplastic. Crit Rev 
Environ Sci Technol. 2019;49(1):32-80. https://doi.org/10.1080/10643389.201 8.1531688.

66. Adam V, Yang T, Nowack B. Toward an ecotoxicological risk assessment of microplastics: comparison of available hazard and exposure data in freshwaters. Environ Toxicol Chem. 2019;38(2):436-47. https://doi.org/10.1 002/etc.4323.

67. Baun A, Eriksson E, Ledin A, Mikkelsen PS. A methodology for ranking and hazard identification of xenobiotic organic compounds in urban stormwater. Sci Total Environ. 2006;370(1):29-38. https://doi.org/10.1016/j. scitotenv.2006.05.017.

68. Björklund K, Cousins AP, Strömvall A-M, Malmqvist P-A. Phthalates and nonylphenols in urban runoff: occurrence, distribution and area emission factors. Sci Total Environ. 2009;407(16):4665-72. https://doi.org/10.1016/j. scitotenv.2009.04.040.

69. Ahlers J, Riedhammer C, Vogliano M, Ebert R-U, Kühne R, Schüürmann G. Acute to chronic ratios in aquatic toxicity — variation across trophic levels and relationship with chemical structure. Env Toxicol. 2006;25(11):2937-45 https://doi.org/10.1897/05-701R.1.

70. Traas TP, Van De Meent D, Posthuma L, Hamers T, Kater BJ, De Zwart D, et al. The potentially affected fraction as a measure of ecological risk. In: Species sensitivity distributions in ecotoxicology. Boca Raton: CRC Press; 2001. p. 315-44. https://www.taylorfrancis.com/books/e/9780429136986/cha pters/10.1201/9781420032314-20.

71. Aldenberg T, Jaworska JS. Uncertainty of the hazardous concentration and fraction affected for normal species sensitivity distributions. Ecotoxicol Environ Saf. 2000;46(1):1-18. https://doi.org/10.1006/eesa.1999.1869.

72. Posthuma L, Suter GW II, Traas TP. Species sensitivity distributions in ecotoxicology. Boca Raton: Lewis Publishers; 2002.

73. Forbes VE, Calow P. Species sensitivity distributions revisited: a critical appraisal. Hum Ecol Risk Assess. 2002;8(3):473-92. https://doi.org/10.1080/1 0807030290879781.

74. Forbes VE, Calow P. Sensitivity distributions - why species selection matters. SETAC Globe. 2002;3(5):22-3.

75. Van Vlaardingen P, Traas T, Wintersen A, Aldenberg T. ETX 2.0. A program to calculate hazardous concentrations and fraction affected, based on normally distributed toxicity data. RIVM Report no. 601501028; 2004.

76. Aldenberg T, Slob W. Confidence limits for hazardous concentrations based on logistically distributed NOEC toxicity data. Ecotoxicol Environ Saf. 1993; 25(1):48-63. https://doi.org/10.1006/eesa.1993.1006.

77. Blaise C, Vasseur P. Algal microplate toxicity test. In: Blaise C, Férard J, editors. Small-scale freshwater toxicity investigations, vol. 1. Dordrecht: Springer; 2005. p. 137-79. https://doi.org/10.1007/1-4020-3120-3_4.

78. Dröge R, Tromp P. Measurements of organic micropollutants, microplastics and associated substances from road transport. In: CEDR Call 2016: environmentally sustainable roads: surface- and groundwater quality MICROPROOF micropollutants in road run-off. Microproof deliverable 6; 2019

79. Klöckner P, Reemtsma T, Eisentraut P, Braun U, Ruhl AS, Wagner S. Tire and road wear particles in road environment - quantification and assessment of particle dynamics by Zn determination after density separation. Chemosphere. 2019;222:714-21. https://doi.org/10.1016/j.chemosphere.2019. 01.176.

80. Eisentraut P, Dümichen E, Ruhl AS, Jekel M, Albrecht M, Gehde M, et al. Two birds with one stone-fast and simultaneous analysis of microplastics: microparticles derived from thermoplastics and tire wear. Environ Sci Technol Lett. 2018;5(10):608-13 Available from: https://pubs.acs.org/doi/10.1 021/acs.estlett.8b00446. Cited 2020 Dec 15.

81. Tromp K. Helofyteninfiltratiesystemen voor zuivering van wegwater onderzoek naar het milieurendement van een helofyteninfiltratiesloot langs de A1 in 't gooi. 2005. Available from: https://edepot.wur.nl/407442

82. Gasperi J, Sebastian C, Ruban V, Delamain M, Percot S, Wiest L, et al. Micropollutants in urban stormwater: occurrence, concentrations, and atmospheric contributions for a wide range of contaminants in three French catchments. Environ Sci Pollut Res. 2014;21(8):5267-81. https://doi. org/10.1007/s11356-013-2396-0.

83. Holsteijn SD. Micropollutants in Berlin's urban rainwater runoff. Berlin: Van Hall Larenstein; 2014. Available from: https://edepot.wur.nl/327101

84. Dsikowitzky L, Schwarzbauer J. Hexa (methoxymethyl)melamine: an emerging contaminant in German rivers. Water Environ Res. 2015;87(5):4619. Available from: http://openurl.ingenta.com/content/xref?genre= article\&issn $=1061-4303 \&$ volume $=87 \&$ issue $=5 \&$ spage $=461$. https: $/ /$ doi.org $/ 1$ $0.2175 / 106143014 \times 14060523640919$.
85. Seitz W, Winzenbacher R. A survey on trace organic chemicals in a German water protection area and the proposal of relevant indicators for anthropogenic influences. Environ Monit Assess. 2017;189(6):244. https://doi. org/10.1007/s10661-017-5953-z.

86. European Commission. European Union Risk Assessment Report COAL-TAR PITCH, HIGH TEMPERATURE. Luxembourg; 2008. Available from: https://echa. europa.eu/documents/10162/433ccfe1-f9a5-4420-9dae-bb316f898fe1

87. European Commission. Proposal for a Directive of the European Parliament and of the Council amending Directives 2000/60/EC and 2008/105/EC as regards priority substances in the field of water policy. Vol. 0429, COM (2011) 876 final; 2012. p. 35.

88. European Commission. European Union Risk Assessment Report 4,4'ISOPROPYLIDENEDIPHENOL (BISPHENOL-A). 2010. Available from: https:// echa.europa.eu/documents/10162/c6a8dcfc-1823-4d31-8a24-2c1168f0d217

89. European Commission. European Union Risk Assessment Report bis (2ethylhexyl) phthalate (DEHP). Luxembourg: Office for Official Publications of the European Communities; 2008. https://doi.org/10.2788/80862.

90. European Commission. Fluoranthene EQS dossier 2011; 2011. p. 1-32.

91. Slobodnik J, Mrafkova L, Carere M, Ferrara F, Pennelli B, Schüürmann G, et al. Identification of river basin specific pollutants and derivation of environmental quality standards: a case study in the Slovak Republic. TrAC - Trends Anal Chem. 2012;41:133-45. https://doi.org/10.1016/j.trac.2012.08.008.

92. ECHA. ECHA registration dossier Benzothiazole-2-thiol. European Chemicals Agency registration dossiers. 2019. Available from: https:/echa.europa.eu/ registration-dossier/-/registered-dossier/13432/6/1\#. Cited 2019 Jul 10.

93. ECHA. Background document to the Opinion on the Annex XV dossier proposing restrictions on NONYLPHENOL and NONYLPHENOL ETHOXYLATES, vol. 1. Helsinki; 2014. Available from: https://echa.europa.eu/ documents/10162/fa20d0e0-83fc-489a-9ee9-01a68383e3c0

94. Brooke D, Footitt A, Nwaogu TA. Environmental risk evaluation report: 4tert-octylphenol. Bristol: Environment Agency; 2005.

95. ECHA. ECHA registration dossier Methyl-1H-benzotriazole. European Chemicals Agency registration dossiers. 2019. Available from: https:/echa. europa.eu/registration-dossier/-/registered-dossier/14272/6/1. Cited 2019 Jul 10.

96. European Commission. Directive 2008/105/EC of the European Parliament and of the Council of 16 December 2008 on environmental quality standards in field of water policy, amending and subsequently repealing Council Directives 82/176/EEC, 83/513/EC, 84/156/EEC, 84/491/EEC, 86/2. Off J Eur. 2008;L348:84-97.

97. Keur MC, Kaag NHBM. Toxicity of 3 water samples tested with the acute fresh crustacean test using Daphnia magna; 2019.

98. Keur MC, Kaag NHBM. Toxicity of 3 water samples tested with the algae growth inhibition test using Raphidocelis subcapitata; 2019.

99. Keur MC, Kaag NHBM. Toxicity of 3 water samples tested with the Bacteria luminescence inhibition test using Vibrio fischeri (Microtox); 2019.

100. Kayhanian M, Stransky C, Bay S, Lau SL, Stenstrom MK. Toxicity of urban highway runoff with respect to storm duration. Sci Total Environ. 2008; 389(2-3):386-406. https://doi.org/10.1016/j.scitotenv.2007.08.052.

101. Hsieh CY, Tsai MH, Ryan DK, Pancorbo OC. Toxicity of the 13 priority pollutant metals to Vibrio fisheri in the Microtox ${ }^{\otimes}$ chronic toxicity test. Sci Total Environ. 2004;320(1):37-50. https://doi.org/10.1016/S0048-9697(03)004 51-0.

102. Van Sprang P, Delbeke K. Acute \& chronic ecotoxicity of soluble copper species in voew of hazard classification of copper and copper compounds. 2019. Available from: https://echa.europa.eu/documents/10162/13626/atta chment_4_copper_flakes_en.pdf.

103. Heijerick DG, Bossuyt BTA, De Schamphelaere KAC, Indeherberg M, Mingazzini M, Janssen CR. Effect of varying physicochemistry of European surface waters on the copper toxicity to the green alga Pseudokirchneriella subcapitata. Ecotoxicology. 2005;14(6):661-70. https://doi.org/10.1007/s1064 6-005-0014-8

104. European Union. Risk assessment report. Zinc metal. Part I - environment. 2010. Available from: http://publications.jrc.ec.europa.eu/repository/handle/ JRC61245.

105. Clément B, Raevel V, Renard O. Ecotoxicological assessment of road runoff residues for aquatic surface ecosystems in a scenario of reuse. J Soils Sediments. 2010;10(7):1255-66. https://doi.org/10.1007/s11368-010-0226-2.

106. Björklund K. Substance flow analyses of phthalates and nonylphenols in stormwater. Water Sci Technol. 2010;62(5):1154-60. https://doi.org/10.2166/ wst.2010.923. 
107. OSPAR. Hazardous substances series: Octylphenol. Publication number 273/ 2006. 2006.

108. Voutsa D, Hartmann P, Schaffner C, Giger W. Benzotriazoles, alkylphenols and bisphenol a in municipal wastewaters and in the Glatt River, Switzerland. Environ Sci Pollut Res. 2006;13(5):333-41. https://doi.org/10.1 065/espr2006.01.295.

109. Kloepfer A, Jekel M, Reemtsma T. Occurence, sources, and fate of Benzothiazoles in municipal wastewater treatment plants. Environ Sci Technol. 2005;39(10):3792-8. https://doi.org/10.1021/es048141e.

110. Liu F, Olesen KB, Borregaard AR, Vollertsen J. Microplastics in urban and highway stormwater retention ponds. Sci Total Environ. 2019;671:992-1000. https://doi.org/10.1016/j.scitotenv.2019.03.416.

111. Koelmans AA, Mohamed Nor NH, Hermsen E, Kooi M, Mintenig SM, De France J. Microplastics in freshwaters and drinking water: Critical review and assessment of data quality. Water Res. Elsevier Ltd. 2019:155:410-22.

112. Kooi M, Koelmans AA. Simplifying microplastic via continuous probability distributions for size, shape, and density. Environ Sci Technol Lett. 2019;6(9): 551-7 Available from: https://pubs.acs.org/sharingguidelines. Cited 2020 Nov 6.

113. Iwasaki Y, Kotani K, Kashiwada S, Masunaga S. Does the choice of NOEC or EC10 affect the hazardous concentration for $5 \%$ of the species? Environ Sci Technol. 2015;49(15):9326-30. https://doi.org/10.1021/acs.est.5b02069.

114. Kooi M, Besseling E, Kroeze C, van Wezel AP, Koelmans AA. Modeling the fate and transport of plastic debris in freshwaters: review and guidance. In: Wagner M, Lambert S, editors. Freshwater microplastics the handbook of environmental chemistry, vol. 58. Cham: Springer; 2018. https://doi.org/10.1 007/978-3-319-61615-5_7.

115. ECHA. Guidance on information requirements and chemical safety assessment. Chapter R.10: Characterisation of dose [concentration]-response for environment. Helsinki: European Chemicals Agency; 2008.

116. De Zwart D, Posthuma L. Complex mixture toxicity for single and multiple species: proposed methodologies. Environ Toxicol Chem. 2005;24(10):266576. https://doi.org/10.1897/04-639R.1.

117. Wang W, Gao H, Jin S, Li R, Na G. The ecotoxicological effects of microplastics on aquatic food web, from primary producer to human: a review. Ecotoxicol Environ Saf. 2019;173(November 2018):110-7.

118. CROW. Polymer properties database. 2019. Available from: https:// polymerdatabase.com/index.html. Cited $2019 \mathrm{Jul} 9$.

119. Fetters LJ, Lohse DJ, Richter D, Witten TA, Zirkel A. Connection between polymer molecular weight, density, chain dimensions, and melt viscoelastic properties. Macromolecules. 1994;27(17):4639-47. https://doi.org/10.1021/ma $00095 a 001$.

120. Khan FR, Halle LL, Palmqvist A. Acute and long-term toxicity of micronized car tire wear particles to Hyalella azteca. Aquat Toxicol. 2019;213:105216. https://doi.org/10.1016/j.aquatox.2019.05.018.

121. Burns EE, Boxall ABA. Corrigendum to: Microplastics in the aquatic environment: Evidence for or against adverse impacts and major knowledge gaps: Microplastics in the environment (Environmental Toxicology and Chemistry, (2018), 37, 11, (2776-2796), 10.1002/etc.4268). Environ Toxicol Chem. 2019:38(3):695.

122. Burns EE, Boxall ABA. Microplastics in the aquatic environment: evidence for or against adverse impacts and major knowledge gaps. Environ Toxicol Chem. 2018;37(11):2776-96. https://doi.org/10.1002/etc.4268.

123. Van Cauwenberghe L. Occurrence, effects and risks of marine microplastics; 2015. p. 215. Available from: http:/www.vliz.be/en/imis?module=ref\&refid= 253398

124. VKM, Skåre JU, Alexander J, Haave M, Jakubowicz I, Knutsen HK, et al, Microplastics; occurrence, levels and implications for environment and human health related to food, Scientific opinion of the Scientific Steering Committee of the Norwegian Scientific Committee for Food and Environment. VKM report 2019:16. Oslo: Norwegian Scientific Committee for Food and Environment (VKM); 2019.

\section{Publisher's Note}

Springer Nature remains neutral with regard to jurisdictional claims in published maps and institutional affiliations.

\section{Submit your manuscript to a SpringerOpen ${ }^{\circ}$ journal and benefit from:}

- Convenient online submission

- Rigorous peer review

- Open access: articles freely available online

- High visibility within the field

- Retaining the copyright to your article

Submit your next manuscript at $\boldsymbol{\nabla}$ springeropen.com 